\title{
ERS statement on exercise training and rehabilitation in patients with severe chronic pulmonary hypertension
}

\author{
Ekkehard Grünig ${ }^{1,25}$, Christina Eichstaedt ${ }^{1,25}$, Joan-Albert Barberà ${ }^{2}$, \\ Nicola Benjamin ${ }^{1}$, Isabel Blanco ${ }^{2}$, Eduardo Bossone ${ }^{3}$, Antonio Cittadini ${ }^{3}$, \\ Gerry Coghlan ${ }^{4}$, Paul Corris $^{5}$, Michele D'Alto ${ }^{6}$, Antonello D'Andrea', \\ Marion Delcroix (10 ${ }^{7}$, Frances de Man ${ }^{8}$, Sean Gaine ${ }^{9}$, Stefano Ghio ${ }^{10}$, \\ Simon Gibbs ${ }^{11}$, Lina Gumbiene ${ }^{12,13}$, Luke S. Howard ${ }^{14}$, Martin Johnson ${ }^{15}$, \\ Elena Jurevičienè ${ }^{12,13}$, David G. Kiely ${ }^{16}$, Gabor Kovacs ${ }^{17,18}$, Alison MacKenzie ${ }^{15}$, \\ Alberto M. Marra ${ }^{19}$, Noel McCaffrey ${ }^{9}$, Paul McCaughey ${ }^{15}$, Robert Naeije ${ }^{20}$, \\ Horst Olschewski ${ }^{17,18}$, Joanna Pepke-Zaba ${ }^{21}$, Abílio Reis $^{22}$, Mário Santos ${ }^{22}$, \\ Stéphanie Saxer ${ }^{23}$, Robert M. Tulloh ${ }^{24}$, Silvia Ulrich ${ }^{23}$, Anton Vonk Noordegraaf ${ }^{8}$ \\ and Andrew J. Peacock ${ }^{15}$
}

@ERSpublications

Specialised exercise training in patients with pulmonary hypertension appears to be effective, costefficient and safe. More support is necessary from healthcare institutions and politicians to establish such programmes throughout Europe. http://ow.ly/kLvS30mUbja

Cite this article as: Grünig E, Eichstaedt C, Barberà J-A, et al. ERS statement on exercise training and rehabilitation in patients with severe chronic pulmonary hypertension. Eur Respir J 2019; 53: 1800332 [https://doi.org/10.1183/13993003.00332-2018].

ABSTRACT Objectives of this European Respiratory Society task force were to summarise current studies, to develop strategies for future research and to increase availability and awareness of exercise training for pulmonary hypertension $(\mathrm{PH})$ patients.

An evidence-based approach with clinical expertise of the task force members, based on both literature search and face-to-face meetings was conducted. The statement summarises current knowledge and open questions regarding clinical effects of exercise training in $\mathrm{PH}$, training modalities, implementation strategies and pathophysiological mechanisms.

In studies (784 PH patients in total, including six randomised controlled trials, three controlled trials, 10 prospective cohort studies and four meta-analyses), exercise training has been shown to improve exercise capacity, muscular function, quality of life and possibly right ventricular function and pulmonary haemodynamics. Nevertheless, further studies are needed to confirm these data, to investigate the impact on risk profiles and to identify the most advantageous training methodology and underlying pathophysiological mechanisms.

As exercise training appears to be effective, cost-efficient and safe, but is scarcely reimbursed, support from healthcare institutions, commissioners of healthcare and research funding institutions is greatly needed. There is a strong need to establish specialised rehabilitation programmes for $\mathrm{PH}$ patients to enhance patient access to this treatment intervention.

This document was endorsed by the ERS Science Council and Executive Committee on November 08 and 28, 2018.

This article has supplementary material available from erj.ersjournals.com

Received: Feb 142018 | Accepted after revision: Sept 122018

Copyright OERS 2019 


\section{Introduction}

Pulmonary hypertension $(\mathrm{PH})$, defined as invasively measured mean pulmonary artery pressure $\geqslant 25 \mathrm{mmHg}$, occurs in many different diseases [1]. The focus of this task force was mainly on patients with pulmonary arterial hypertension (PAH) and chronic thromboembolic pulmonary hypertension (CTEPH). Here, these are summarised as $\mathrm{PH}$ unless otherwise stated. In the past decade great advances in medical therapy have been made [1]. Despite optimised medical treatment, most $\mathrm{PH}$ patients still suffer from symptoms, reduced exercise capacity and quality of life (QoL) and disease progression [2]. In most cases medication cannot entirely halt or reverse right ventricular dysfunction nor normalise pulmonary vascular resistance. Consequently, the need of non-pharmacological, high-quality treatments is rapidly growing.

Exercise training is one of the most important, safest and cost-effective treatment options, and has been shown to be beneficial in a wide range of diseases. In addition, it is strongly advocated in the healthy population to improve QoL, wellbeing and muscular strength [3]. The entire body including the heart is impacted upon by being physically active. Hence, haemodynamic differences can be noted in athletes in comparison to controls with a less active lifestyle [4]. In particular, long-term endurance exercise increased the size of the right ventricle and improved early diastolic right ventricular function [5] and left ventricular stiffness [6]. In contrast, a sedentary lifestyle in healthy subjects has been established as an independent risk factor for insulin resistance acting in concert with other cardiovascular risk factors such as smoking, obesity and high blood pressure [7]. Thus, moderate physical activity has been recommended for the prevention of several cardiovascular diseases [8].

Training for patients with left heart failure received a 1A recommendation in the recent guidelines [9], as it was shown to improve QoL $[10,11]$ and exercise capacity [12], reduce the risk of heart failure associated hospitalisation [9,11] and even morbidity events [10]. The training should be supervised carefully as heavy physical activity, particularly in untrained individuals, can increase the risk of myocardial infarction [13]. Patients suffering from coronary artery disease are thus advised to participate in cardiac rehabilitation programmes to reduce cardiovascular mortality and hospitalisation events [14].

In contrast, for $\mathrm{PH}$ patients, these exercise recommendations have been lacking for a long time and in fact, physical activity has been discouraged due to the risk of worsening of the disease, right ventricular decompensation and sudden cardiac death. In most $\mathrm{PH}$ patients at time of diagnosis the right ventricle is increased in size and impaired in function [2]. There is concern that wall shear stress on the pulmonary vessels, evoked by higher blood flow due to exercise training, may trigger pulmonary vascular remodelling and worsen the disease; thus, in any exercise regimen extreme caution has to be warranted not to overexert these patients. A specialised, low-intensity, individually adjusted, closely supervised exercise training regimen has been developed and a first randomised controlled trial demonstrated its safety and feasibility [15]. Due to a growing body of evidence [15-23], in the recent guidelines a supervised and closely monitored exercise and respiratory training programme in specialised clinics as an add-on to medical therapy has been recommended for stable PH patients (class II, level of evidence B) [1]. Currently, exercise training for $\mathrm{PH}$ patients is only routinely reimbursed by insurance programmes or state funding in very few countries. Therefore, exercise training prescription as supportive therapy is limited. Furthermore, the

Affiliations: ${ }^{1}$ Centre for Pulmonary Hypertension, Thoraxclinic at the University Hospital Heidelberg Translational Lung Research Center Heidelberg (TLRC), German Center for Lung Research (DZL), Heidelberg, Germany. ${ }^{2}$ Hospital Clinic IDIBAPS, University of Barcelona, Barcelona and Biomedical Research Networking Center on Respiratory Diseases, Madrid, Spain. ${ }^{3}$ Dept of Cardiac Surgery, University Hospital Salerno, Salerno, Italy. ${ }^{4}$ Pulmonary Hypertension Unit, Royal Free Hospital, University College London, London, UK. ${ }^{5}$ Dept of Respiratory Medicine, Freeman Hospital, University of Newcastle, Newcastle upon Tyne, UK. ${ }^{6}$ Dept of Cardiology, Second University of Naples - Monaldi Hospital, Naples, Italy. ${ }^{7}$ Dept of Pneumology, University Hospital Leuven, Leuven, Belgium. ${ }^{8}$ Dept of Pulmonology, VU University Medical Center Amsterdam, Amsterdam, The Netherlands. ${ }^{9}$ Dept of Respiratory Medicine, Mater Misericordiae University Hospital, Dublin, Ireland. ${ }^{10}$ Divisione di Cardiologia, Fondazione IRCCS Policlinico S Matteo, Pavia, Italy. ${ }^{11}$ Faculty of Medicine, Imperial College London, National Heart and Lung Institute, London, UK. ${ }^{12}$ Competence Centre of Pulmonary Hypertension, Vilnius University Hospital Santaros Klinikos, Vilnius, Lithuania. ${ }^{3}$ Faculty of Medicine, Vilnius University, Vilnius, Lithuania. ${ }^{14}$ Hammersmith Hospital, Imperial College NHS Trust, London, UK. ${ }^{15}$ Scottish Pulmonary Vascular Unit, Golden Jubilee National Hospital, Glasgow, UK. ${ }^{16}$ Sheffield Pulmonary Vascular Disease Unit, Royal Hallamshire Hospital, Sheffield, UK. ${ }^{17}$ Dept of Internal Medicine, Div. Pulmonology, Medical University of Graz, Graz, Austria. ${ }^{18}$ Ludwig Boltzmann Institute for Lung Vascular Research, Graz, Austria. ${ }^{19}$ Dept of Cardiovascular Imaging, IRCCS S.D.N., Naples, Italy. ${ }^{20}$ Dept of Cardiology, University Clinic Brussels - Erasme Hospital, Brussels, Belgium. ${ }^{21}$ Pulmonary Vascular Disease Unit, Papworth Hospital, Cambridge, UK. ${ }^{22}$ Dept of Internal Medicine, Hospital Geral de Santo António, Porto, Portugal. ${ }^{23}$ Centre for Pulmonary Hypertension, University Hospital Zurich, Zurich, Switzerland. ${ }^{24}$ Dept of Congenital Heart Disease, Bristol Royal Hospital for Children, Bristol, UK. ${ }^{25}$ Both authors contributed equally.

Correspondence: Ekkehard Grünig, Centre for Pulmonary Hypertension, Thoraxklinik at Heidelberg University Hospital, Röntgenstraße 1, 69126 Heidelberg, Germany. E-mail: ekkehard.grueniglamed.uni-heidelberg.de 
best training modalities, individual adaptation and the optimal setting for this rehabilitation remain to be determined. Pathophysiological mechanisms are not completely clear.

The objectives of this European Respiratory Society (ERS) task force were to summarise the current state of knowledge and open questions regarding the clinical effects of exercise training, training modalities and mechanisms of action in patients with $\mathrm{PH}$. Furthermore, it aimed to develop strategies for future research and implementation of a standardised $\mathrm{PH}$ rehabilitation programme in European countries to increase awareness and availability of this potentially important add-on therapy.

\section{Methodology}

In this ERS task force statement, $\mathrm{PH}$ experts were involved from 18 centres in 11 European countries. The task force members were selected by the chairs (E. Grünig and A. Peacock) according to their expertise in $\mathrm{PH}$ and exercise training in $\mathrm{PH}$. The statement was reviewed by the $\mathrm{PH}$ patient organisation PHA Europe. All task force members completed conflict of interest forms.

The present ERS statement combines an evidence-based approach with the clinical expertise of the task force members, based on both literature search and face-to-face meetings. Subgroups of authors were formed for each section at a first face-to-face meeting (September 5, 2016). These groups prepared individual subsections, which were then presented and discussed within the entire group in a second meeting (September 11, 2017) and subsequently revised until consent among all co-authors was reached. All co-authors critically revised and approved the final statement.

Literature search was conducted using MEDLINE including phrases such as "exercise training", "rehabilitation", "pulmonary hypertension" and the relevant key words for each respective section (supplementary table S1). Identified original articles on exercise training in $\mathrm{PH}$ were used for the sections on clinical effects, training modalities and setting, implementation and mechanisms of action. The search was restricted to articles available in English. No time limitation was introduced to identified articles. Data from case reports of single patients, children and adolescents, clinical trial protocols and abstracts only were excluded. The literature search was performed in May 2015 and repeated after the task force meetings and at the end of the task force period in December 2017 to include latest publications. Additionally, hand searches of articles listed in the references lists were performed.

This document aims to provide an overview of the literature and current evidence and does not provide a systematic review or recommendations for clinical practice.

\section{Part I: clinical effects of exercise training in pulmonary hypertension} Effect of exercise training on exercise capacity and QoL

The clinical impact of exercise training in $\mathrm{PH}$ has been investigated in several studies with 784 patients in total, including six randomised controlled trials [15, 22-26], three controlled trials [27-29], 10 prospective cohort studies [16-21,30-35], three case series [34-36], two retrospective cohort studies [37, 38] and four meta-analyses [39-42] (table 1). In the first prospective randomised controlled trial in patients with severe chronic $\mathrm{PH}$, exercise training improved the primary end-point, 6-min walk distance (6MWD), by $96 \pm 61 \mathrm{~m}$ after 15 weeks compared to the control group $(\mathrm{p}<0.0001)$ [15]. This positive result was supported by a further randomised controlled trial [22] and a prospective uncontrolled trial including 183 patients with different $\mathrm{PH}$ aetiologies [19]. Patients in World Health Organization (WHO) functional class IV presented with the strongest improvements, compared to functional classes II and III [19]. One recent randomised controlled study has demonstrated a significant increase of the primary end-point, mean peak oxygen uptake $\left(V^{\prime} \mathrm{O}_{2}\right)$, which improved up to almost $25 \%$ in the training group versus the control group $\left(+3.1 \pm 2.7 \mathrm{~mL} \cdot \mathrm{min}^{-1} \cdot \mathrm{kg}^{-1}\right.$ versus $\left.-0.2 \pm 2.3 \mathrm{~mL} \cdot \mathrm{min}^{-1} \cdot \mathrm{kg}^{-1} ; \mathrm{p}<0.0001\right)[24]$.

The effects of exercise training on exercise capacity have been verified by four meta-analyses showing an improvement in 6MWD (53-72 m), peak $V^{\prime} \mathrm{O}_{2}\left(1.5-2.2 \mathrm{~mL} \cdot \mathrm{min}^{-1} \cdot \mathrm{kg}^{-1}\right)$ and workload (14.9 W) [39-42].

Exercise training performed in patients classified into different groups of $\mathrm{PH}$ has not only improved exercise capacity, but also different aspects of QoL, as shown in several studies [15, 17, 22] (table 2). Most studies used the 36-item short-form health survey (SF-36) questionnaire, a generic instrument. MereLES et al. [15] showed a significant improvement in the primary end-point, QoL, in the two summation scores and in five SF-36 subscales after 15 weeks of exercise training in severe chronic $\mathrm{PH}$ [20]. Further prospective studies confirmed improvements of SF-36 subscales in stable PAH and CTEPH at 3 months of follow-up [17, 19, 24]. Details of improvement in QoL are given in table 2. The improvements measured by SF-36 scales with different training modalities in various PH groups suggest a significant impact of exercise training on patients' QoL, which has been confirmed by a meta-analysis [41] and a Cochrane review [42] showing significant improvements in the SF-36 subscales: physical function, role physical, general health, social function, role emotional and vitality.This is remarkable, as the generic SF-36 
TABLE 1 Studies on exercise training in patients with pulmonary hypertension including design and main results

\begin{tabular}{|c|c|c|c|c|c|}
\hline First author, year [ref] & Study design & Sample & $\begin{array}{l}\text { Diagnoses and severity } \\
\text { of disease }\end{array}$ & $\begin{array}{l}\text { Results parameters with significant } \\
\text { improvement }{ }^{\#}\end{array}$ & $\begin{array}{c}\text { Parameters without significant improvement of } \\
\text { deterioration ? }\end{array}$ \\
\hline \multicolumn{6}{|l|}{$\begin{array}{l}\text { Randomised controlled trials } \\
\qquad n=6 ; \text { patients } \\
n=224\end{array}$} \\
\hline MeReLES, 2006 [15] & $\begin{array}{l}\text { Randomised } \\
\text { controlled trial }\end{array}$ & 30 & $\begin{array}{l}\text { IPAH }(80 \%) \\
\text { CTEPH }(20 \%) \\
\text { WHO-FC II-IV }\end{array}$ & $\begin{array}{c}\text { Primary: } 6 \mathrm{MWD}, \mathrm{QoL}(\mathrm{SF}-36) \\
\text { Secondary: WHO-FC, peak } V^{\prime} \mathrm{O}_{2}, V^{\prime} \mathrm{O}_{2} \text { at anaerobic } \\
\text { threshold, workload, systolic pulmonary arterial } \\
\text { pressure at rest (echocardiography) }\end{array}$ & \multirow[t]{2}{*}{$\begin{array}{l}\text { No change: Borg scale, heart rate at rest, right } \\
\text { heart size and function (echocardiographyl }\end{array}$} \\
\hline WEINSTEIN, 2013 [23] & $\begin{array}{l}\text { Randomised } \\
\text { controlled trial }\end{array}$ & 24 & $\begin{array}{l}\text { APAH/IPAH (75\%/25\%) } \\
\text { WHO-FC I-IV }\end{array}$ & $\begin{array}{c}\text { Fatigue, physical activity } \\
\text { 6MWD, treadmill exercise test duration, peak } \\
\text { power output }\end{array}$ & \\
\hline CHAN, 2013 [22] & $\begin{array}{l}\text { Randomised } \\
\text { controlled trial }\end{array}$ & 23 & $\begin{array}{l}\text { APAH/IPAH }(74 \% / 22 \%) \\
\text { WHO-FC I-IV }\end{array}$ & $\begin{array}{c}\text { Primary: 6MWD } \\
\text { Secondary: time to exercise intolerance, peak } \\
\text { workload, peak } \text { PETCO }_{2} \text {, time to anaerobic threshold, } \\
\text { QoL (SF-36, CAMPHOR) }\end{array}$ & \multirow[t]{2}{*}{$\begin{array}{l}\text { No change: peak } V^{\prime} \mathrm{o}_{2} \text {, haemodynamics } \\
\text { (bioimpedance cardiography: cardiac index, } \\
\text { cardiac output, stroke volume) }\end{array}$} \\
\hline LEY, 2013 [25] & $\begin{array}{l}\text { Randomised } \\
\text { controlled trial }\end{array}$ & 20 & $\begin{array}{l}\text { APAH/IPAH }(20 \% / 55 \%) \\
\text { CTEPH }(20 \%) \\
\text { WHO-FC II-III }\end{array}$ & $\begin{array}{c}\text { Primary: mean blood flow peak velocity within } \\
\text { cardiac MRI } \\
\text { Secondary: perfusion (mean pulmonary blood } \\
\text { volume), 6MWD }\end{array}$ & \\
\hline EHLKEN, 2016 [24] & $\begin{array}{l}\text { Randomised } \\
\text { controlled trial }\end{array}$ & 87 & $\begin{array}{l}\text { PAH }(70 \%) \\
\text { CTEPH }(30 \%) \\
\text { WHO-FC II-IV }\end{array}$ & $\begin{array}{c}\text { Primary: peak } \mathrm{V}^{\prime} \mathrm{O}_{2} \\
\text { Secondary: haemodynamics (cardiac index at rest } \\
\text { and during exercise), 6MWD, QoL (SF-36) }\end{array}$ & $\begin{array}{c}\text { No change: NT-proBNP, heart rate at rest, peak } \\
\text { mPAP, peak PVR }\end{array}$ \\
\hline GonzálezZ-SAIZ, 2017 [26] & $\begin{array}{l}\text { Randomised } \\
\text { controlled trial }\end{array}$ & 40 & $\begin{array}{l}\text { APAH/IPAH }(35 \% / 25 \%) \\
\text { CTEPH }(10 \%) \\
\text { NYHA-FC I-III }\end{array}$ & $\begin{array}{c}\text { Primary: peak muscle power during bench/leg } \\
\text { press } \\
\text { Secondary: peak } V^{\prime} 0_{2}, 6 M W D \text {, five-repetition } \\
\text { sit-to-stand, moderate-vigorous physical activity }\end{array}$ & $\begin{array}{c}\text { No change: QoL (SF-12), 6MWD, peak } V^{\prime} \mathrm{O}_{2} \\
\text { NT-proBNP }\end{array}$ \\
\hline \multicolumn{6}{|l|}{$\begin{array}{l}\text { Non-randomised } \\
\text { controlled trials } n=3 ; \\
\text { patients } n=71\end{array}$} \\
\hline $\begin{array}{l}\text { Martínez-QuintanA, } \\
2010 \text { [28] }\end{array}$ & $\begin{array}{l}\text { Non-randomised } \\
\text { controlled trial }\end{array}$ & 8 & $\begin{array}{l}\text { CHD-APAH (100\%) } \\
\text { WHO-FC II-III }\end{array}$ & NYHA-FC & $\begin{array}{l}\text { No change: QoL (SF-36), 6MWD, peripheral } \\
\text { muscle function, NT-proBNP }\end{array}$ \\
\hline Fox, 2011 [27] & $\begin{array}{l}\text { Non-randomised } \\
\text { controlled trial }\end{array}$ & 22 & $\begin{array}{l}\text { APAH/IPAH }(46 \% / 45 \%) \\
\text { CTEPH }(9 \%) \\
\text { WHO-FC II-III }\end{array}$ & $\begin{array}{l}\text { Primary: } 6 \mathrm{MWD} \text {, peak } V^{\prime} \mathrm{O}_{2} \\
\text { Secondary: no significant changes }\end{array}$ & $\begin{array}{c}\text { No change: NT-proBNP, pulse pressure, Borg } \\
\text { scale, peak oxygen saturation, peak workload, } \\
\text { oxygen uptake efficiency, } V^{\prime} \mathrm{E} / V^{\prime} \mathrm{CO}_{2}\end{array}$ \\
\hline FuKUI, 2016 [29] & $\begin{array}{l}\text { Non-randomised } \\
\text { controlled trial }\end{array}$ & 41 & $\begin{array}{l}\text { CTEPH (100\%) } \\
\text { WHO-FC I-III }\end{array}$ & $\begin{array}{c}\text { Peak } V^{\prime} \mathrm{O}_{2} \text {, workload, WHO-FC, quadriceps strength, } \\
\text { oxygen pulse }\end{array}$ & $\begin{array}{c}\text { No change: QoL (SF-36), 6MWD, NT-proBNP, } V^{\prime} 0 \\
\text { at anaerobic threshold, heart rate at rest, oxyger } \\
\text { saturation, } V^{\prime} E / V^{\prime} \mathrm{CO}_{2}, 6 \mathrm{MWD} \text {, forearm muscle } \\
\text { strength }\end{array}$ \\
\hline \multicolumn{6}{|l|}{$\begin{array}{l}\text { Prospective uncontrolled } \\
\text { cohort studies } n=10 ; \\
\text { patients } n=426\end{array}$} \\
\hline DE MAN, 2009 [21] & Prospective cohort & 19 & $\begin{array}{l}\text { IPAH (100\%) } \\
\text { WHO-FC II-III }\end{array}$ & $\begin{array}{l}\text { Workload, exercise endurance time, quadriceps } \\
\text { strength and endurance, increase of capillarisation }\end{array}$ & No change: 6MWD, endurance, NT-proBNP \\
\hline
\end{tabular}


TABLE 1 Continued

First author, year [ref]

Study design

GRÜNIG, $2011[20]$

Prospective cohort

58

of disease

6MWD, peak $V^{\prime} \mathrm{O}_{2}$, QoL (SF-36), WHO-FC, workload, heart rate at rest (decrease) and peak (increase), $V$

$\mathrm{O}_{2}$ at anaerobic threshold, workload at anaerobic

GRÜNIG, 2012 [19]

Prospective cohort

183

CTEPH $(10 \%)$

NAGEL, 2012 [17]

Prospective cohort

35

GRÜNIG, 2012 [18]

Prospective cohort

BeCKer-GrünIG, 2013 [16]

Prospective cohort

KABITZ, 2014 [31]

EHLKEN, 2014 [30]

INAGAKI, 2014 [32]

Prospective cohort

Prospective cohort versus retrospective control group

Prospective cohort

7

APAH /IPAH (28\%/72\%)

$58^{+}$

\section{IHLE, 2014 [33]}

Prospective cohort

17

\section{Case reports and}

retrospective studies $n=5$;

patients $\mathrm{n}=63$

SHOEMAKER, 2009 [35]

Case reports

MaInGUY, 2010 [34]
Case series
CTD-APAH (100\%)

WHO-FC II-IV

CHD-APAH (100\%) WHO-FC II-III

WHO-FC III-IV

APAH/IPAH (12\%/63\%) CTEPH $(10 \%)$ WHO-FC II-IV

CTEPH (100\%) WHO-FC II-III

PAH $(82 \%)$

CTEPH $(18 \%)$

WHO-FC II-III

$6 \mathrm{MWD}$, peak $\mathrm{V}^{\prime} \mathrm{O}_{2}, \mathrm{QoL}$ (SF-36), $\mathrm{V}^{\prime} \mathrm{O}_{2}$ at anaerobic threshold, oxygen pulse, systolic pulmonary arterial pressure at rest, workload

6MWD, peak $V^{\prime} \mathrm{O}_{2}$, QoL (SF-36), workload Survival 11 year $97 \%$, 2 years $94 \%$, 3 years $86 \%$

6MWD, peak $V^{\prime} \mathrm{O}_{2}, \mathrm{QoL}(\mathrm{SF}-36)$, heart rate at rest, oxygen saturation, workload, $\mathrm{V}^{\prime} \mathrm{O}_{2}$ at anaerobic threshold threshold 2 years $100 \%, 3$ years $73 \%$

6MWD, peak $V^{\prime} \mathrm{O}_{2}$, workload Survival (1 year $100 \%, 2$ years 93\%) QoL (bodily pain)

Respiratory muscle strength, 6MWD

QoL, lower estimated healthcare costs due to fewer worsening events

6MWD, QoL, quadriceps force, QoL ISt George's Respiratory Questionnaire: activity), intensity of physical activity

QoL (CAMPHOR: activity)

APAH/IPAH $(50 \% / 50 \%)$

WHO-FC I

IPAH (100\%) WHO-FC II-III at anaerobic threshold in both subjects

6MWD, V'E

Decreased type IIx muscle fibre proportion threshold Parameters without significant improvement or
deterioration

No change: Borg Scale, respiratory equivalent for carbon dioxide

No change: Borg Scale, respiratory equivalent for carbon dioxide

No change: WHO-FC, NT-proBNP, oxygen saturation, oxygen pulse, respiratory equivalent for carbon dioxide

Significantly higher Borg scale after intervention

No change: WHO-FC, Borg scale, oxygen pulse,

oxygen saturation at rest, haemodynamics

lechocardiography), C-reactive protein, leukocytes

No change: QoL (SF-36 except bodily pain), WHO-FC, haemodynamics (echocardiography), oxygen pulse, $\mathrm{V}^{\prime} \mathrm{O}_{2}$ at anaerobic threshold, oxygen saturation, Borg scale Deterioration: NT-proBNP

No change: dyspnoea, WHO-FC, heart rate at rest, pulmonary function, activities of daily living, QoL (St George's Respiratory Questionnaire: symptom and impact), haemodynamics (echocardiography), dyspnoea and functional status, BNP, steps per day

No change: QoL (SF-36, CAMPHOR: symptoms, QoL), 6MWD

\section{QoL (1 out of 2 subjects improved)}




\begin{tabular}{|c|c|c|c|c|c|}
\hline First author, year [ref] & Study design & Sample & $\begin{array}{l}\text { Diagnoses and severity } \\
\text { of disease }\end{array}$ & $\begin{array}{l}\text { Results parameters with significant } \\
\text { improvement }{ }^{\#}\end{array}$ & $\begin{array}{c}\text { Parameters without significant improvement or } \\
\text { deterioration" }\end{array}$ \\
\hline RASKIN, 2014 [37] & Retrospective cohort & 23 & $\begin{array}{l}\text { Aetiology not reported } \\
\text { WHO-FC II-IV }\end{array}$ & $\begin{array}{l}\text { Primary: 6MWD (especially when baseline 6MWD } \\
\text { was lower) } \\
\text { Secondary: dyspnoea impact (clinically significant: } \\
\text { subscale St George's Respiratory Questionnaire) }\end{array}$ & $\begin{array}{l}\text { No change: QoL (clinically significant: St George's } \\
\text { Respiratory Questionnaire: two main parts) } \\
\text { Deterioration: QoL (clinically significant: St } \\
\text { George's Respiratory Questionnaire: activity) }\end{array}$ \\
\hline TALWAR, 2017 [38] & Retrospective cohort & 18 & $\begin{array}{l}\text { PAH (100\%) } \\
\text { WHO-FC I-IV }\end{array}$ & Treadmill speed & No change: exercise time \\
\hline Bussotti, 2017 [36] & Case series & 15 & $\begin{array}{l}\text { APAH/IPAH (53\%/47\%) } \\
\text { WHO-FC II-III }\end{array}$ & $\begin{array}{c}\text { Primary: peak } V^{\prime} \mathrm{o}_{2} \\
\text { Secondary: } 6 \mathrm{MWD} \text {, oxygen pulse, maximal heart } \\
\text { rate, peak workload, QoL }\end{array}$ & No change: NT-proBNP \\
\hline $\begin{array}{l}\text { Meta-analysis } \mathbf{n}=\mathbf{4} \\
\text { YUAN, } 2015 \text { [41] }\end{array}$ & Meta-analysis & $\begin{array}{c}12 \\
\text { studies } \\
\text { total } \\
\mathrm{n}=449\end{array}$ & $\begin{array}{l}\text { Different aetiologies of } \\
\text { pulmonary } \\
\text { hypertension }\end{array}$ & $\begin{array}{c}\text { 6MWD }(62.2 \mathrm{~m}, 95 \% \mathrm{Cl} 45.6-78.8 \mathrm{~m}) \\
\text { Peak } V^{\prime} \mathrm{O}_{2} \cdot \mathrm{kg}^{-1} \text {, workload } \\
\mathrm{V}^{\prime} \mathrm{O}_{2} \text { at anaerobic threshold } \\
\text { Heart rate at rest lafter } 3 \text { weeks) } \\
\text { QoL (physical function 10.4, 95\% } \mathrm{Cl} 5.0-15.9 \text {; role } \\
\text { physical } 12.1,95 \% \mathrm{Cl} 1.3-23.0 \text {; general health } 4.0 \text {, } \\
95 \% \mathrm{Cl} 0.04-7.9 \text {; social function } 11.6,95 \% \mathrm{Cl} 5.2- \\
17.9 \text {; role emotional } 14.3,95 \% \mathrm{Cl} 6.2-11.4 \text { ) }\end{array}$ & No change: heart rate at rest (after $12-15$ weeks) \\
\hline Buys, 2015 [39] & Meta-analysis & $\begin{array}{c}5 \\
\text { studies } \\
\text { total } \\
\mathrm{n}=106\end{array}$ & $\begin{array}{l}\text { Different } \\
\text { aetiologies of } \\
\text { pulmonary } \\
\text { hypertension }\end{array}$ & $\begin{array}{c}\text { 6MWD }(72.5 \mathrm{~m}, 95 \% \mathrm{Cl} 46.0-99.1) \\
\text { Peak } V^{\prime} \mathrm{O}_{2} \cdot \mathrm{kg}^{-1}\end{array}$ & \\
\hline PANDEY, 2015 [40] & Meta-analysis & $\begin{array}{l}16 \\
\text { studies } \\
\text { total } \\
n=469\end{array}$ & $\begin{array}{l}\text { Different } \\
\text { aetiologies of } \\
\text { pulmonary } \\
\text { hypertension }\end{array}$ & $\begin{array}{c}\text { 6MWD (53.3 m, } 95 \% \mathrm{Cl} 39.5-67.2 \mathrm{~m}) \\
\text { Peak } \mathrm{V}^{\prime} \mathrm{O}_{2} \cdot \mathrm{kg}^{-1} \\
\text { QoL }\end{array}$ & - \\
\hline MoRRIS, 2017 [42] & $\begin{array}{l}\text { Cochrane } \\
\text { meta-analysis }\end{array}$ & $\begin{array}{c}6 \\
\text { studies } \\
\text { total } \\
\mathrm{n}=206\end{array}$ & $\begin{array}{l}\text { Different aetiologies of } \\
\text { pulmonary } \\
\text { hypertension }\end{array}$ & $\begin{array}{c}\text { 6MWD (60.1 m, 95\% Cl 30.2-90.1) } \\
\text { Peak } V^{\prime} \mathrm{O}_{2} \cdot \mathrm{kg}^{-1} \\
\text { QoL (SF-36 summation scores, role physical 21.8, } \\
\text { 95\% Cl 14.4-29.2; vitality 13.5, 95\% Cl 7.6-19.4; } \\
\text { social function 14.0, 95\% } \mathrm{Cl} 9.8-18.2 ; \text { CAMPHOR: } \\
\text { QoL) } \\
\text { Peak power }\end{array}$ & $\begin{array}{l}\text { No change: adverse events, functional class, } \\
\text { NT-proBNP, QoL (SF-36: physical function, bodily } \\
\text { pain, general health, mental health, role } \\
\text { emotional; CAMPHOR: activities, symptoms) }\end{array}$ \\
\hline \multicolumn{6}{|c|}{ 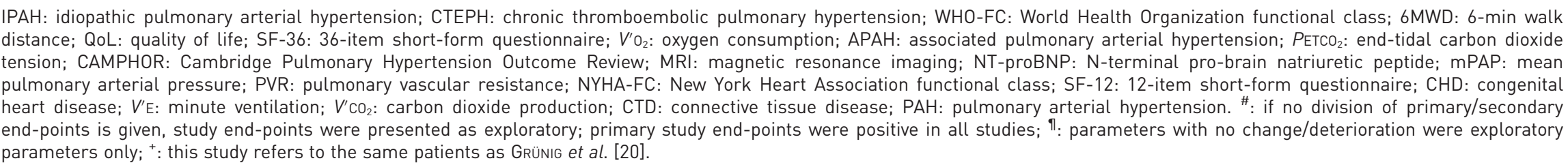 } \\
\hline
\end{tabular}


TABLE 2 Quality-of-life (QoL) outcomes in exercise training studies of pulmonary hypertension patients

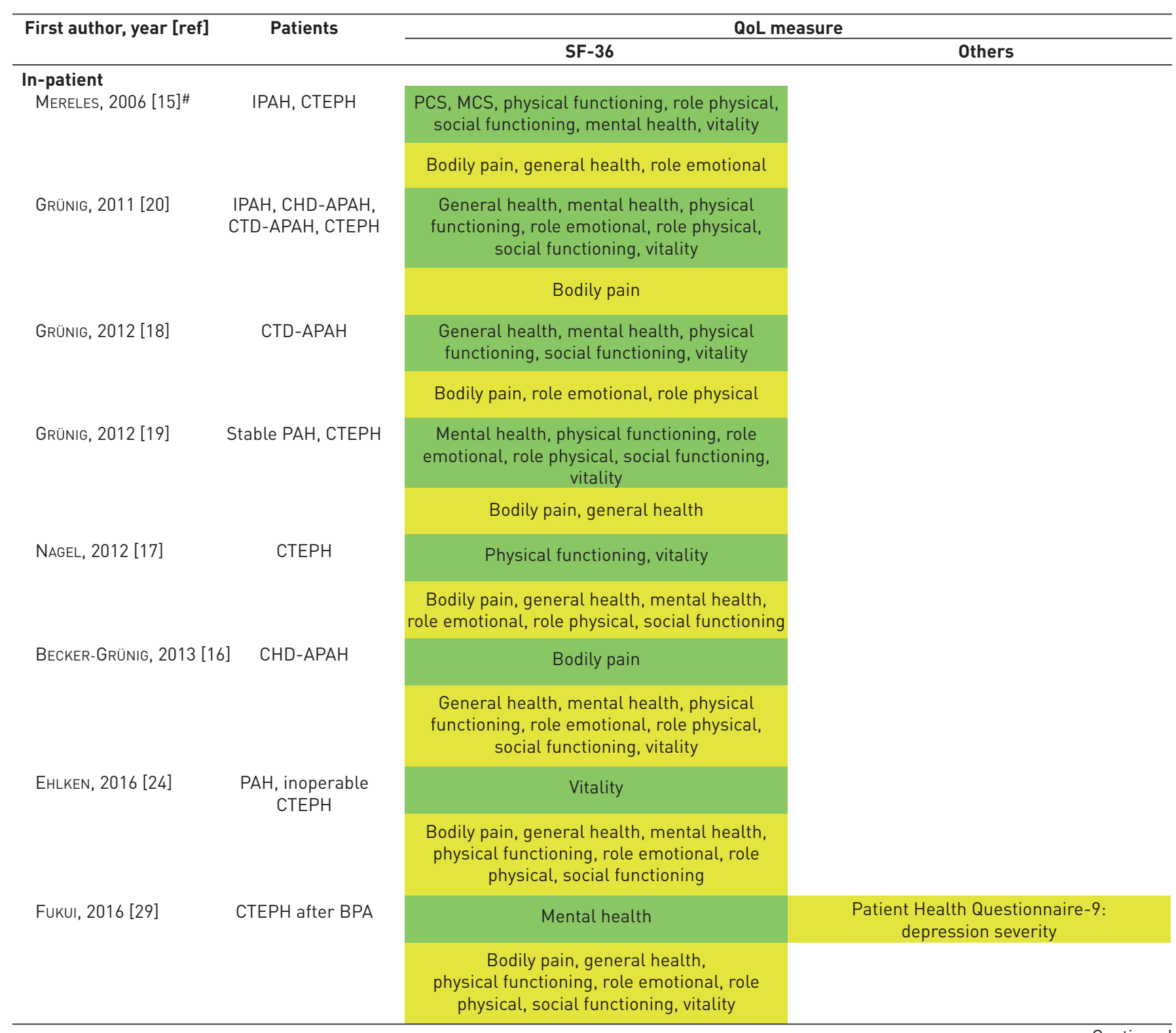

instrument is designed to compare QoL in health and various diseases, but is usually less sensitive to detect changes under therapy compared with disease-specific instruments. In summary, most of the studies presented a significant improvement in exercise capacity and/or some QoL subscales.

\section{Haemodynamics and echocardiography}

Most exercise training trials published so far in the field of $\mathrm{PH}$ focused on changes in exercise capacity. There is only one prospective, randomised, controlled trial available, which aimed to assess changes systematically with invasively measured haemodynamics at rest and during exercise as secondary end-points [24]. Altogether, 79 patients, either suffering from PAH or from nonoperable CTEPH, finished this study and 73 of them underwent right heart catheterisations at baseline and after 15 weeks. The study revealed a significant increase in cardiac index $(+9.3 \%$ versus $-6.5 \% ; \mathrm{p}<0.001)$, significant decreases in mean pulmonary arterial pressure $(-7.3 \%$ versus $+16.1 \%$; $\mathrm{p}=0.007)$ and pulmonary vascular resistance $(-19.3 \%$ versus $+34.5 \% ; \mathrm{p}<0.001)$ at rest and a significant increase in cardiac index $(+19.5 \%$ versus $-4.3 \%$; 
TABLE 2 Continued

\begin{tabular}{|c|c|c|c|}
\hline \multirow[t]{2}{*}{ First author, year [ref] } & \multirow[t]{2}{*}{ Patients } & \multicolumn{2}{|c|}{ QoL measure } \\
\hline & & SF-36 & Others \\
\hline \multicolumn{4}{|c|}{ Outpatient } \\
\hline \multirow{2}{*}{ GonZÁLEZ-SAIZ, 2017 [26] } & 6] Stable PAH, & Role physical, vitality & \\
\hline & & $\begin{array}{l}\text { Bodily pain, general health, mental health, } \\
\text { physical functioning, role emotional, } \\
\text { social functioning }\end{array}$ & \\
\hline \multirow[t]{2}{*}{ CHAN, 2013 [22] } & $\begin{array}{l}\text { IPAH, CTD-APAH, } \\
\text { drug-induced PAH }\end{array}$ & $\begin{array}{c}\text { General health, mental health, physical } \\
\text { functioning, role physical, social functioning, } \\
\text { vitality }\end{array}$ & $\begin{array}{l}\text { CAMPHOR: QoL, symptoms, energy, } \\
\text { breathlessness, mood }\end{array}$ \\
\hline & & Bodily pain, role emotional & CAMPHOR: functioning \\
\hline \multirow{2}{*}{ RASKIN, 2014 [37] } & & & SGRQ: symptom \\
\hline & & & SGRQ: activity score \\
\hline ZöLLER, 2017 [43] & $\begin{array}{l}\text { PAH (children and } \\
\text { adolescents) }\end{array}$ & Tendency: MCS, PCS & \\
\hline Bussottı, 2017 [36] & $\begin{array}{l}\text { IPAH, portal } \\
\text { hypertension-APAH, } \\
\text { CTD-APAH, HIV-APAH }\end{array}$ & & $\begin{array}{l}\text { HADS questionnaire: anxiety, depression; } \\
\text { EuroQoL-5 dimensions; EuroQoL-visual } \\
\text { analogue scale }\end{array}$ \\
\hline GERHARDT, 2017 [44] & $\begin{array}{l}\text { IPAH, HPAH, } \\
\text { CTD-APAH }\end{array}$ & MCS, PCS & $\begin{array}{l}\text { Living with PH survey; physical and } \\
\text { emotional dimension score }\end{array}$ \\
\hline \multicolumn{4}{|l|}{ Home } \\
\hline IHLE, 2014 [33] & & physical, social functioning, vitality & CAMPHOR: QoL, symptoms \\
\hline
\end{tabular}

SF-36: 36-item short form questionnaire; IPAH: idiopathic pulmonary arterial hypertension; CTEPH: chronic thromboembolic pulmonary hypertension; PCS: physical component score; MCS: mental component score; CHD: congenital heart disease; APAH: associated pulmonary arterial hypertension; CTD: connective tissue disease; PAH: pulmonary arterial hypertension; BPA: balloon angioplasty; SF-12: 12-item short form questionnaire; CAMPHOR: Cambridge Pulmonary Hypertension Outcome Review; SGRQ: St George's Respiratory Questionnaire; HADS: Hospital Anxiety and Depression Scale; HPAH: hereditary pulmonary arterial hypertension. * : co-primary end-point.

$\mathrm{p}=0.002$ ) during maximal exercise in the training group, compared with the control group. The observed haemodynamic changes during exercise may be of special importance, as recent data suggest that cardiac index during exercise may represent an independent predictor of survival in PAH [45]. Interestingly, echocardiography showed no statistically significant change in right heart areas and systolic pulmonary arterial pressure between the groups in this study.

Echocardiography has been performed in most exercise training studies in order to estimate systolic pulmonary arterial pressure and right ventricular functional variables. The results of these studies have been evaluated in a meta-analysis [40]. Although not all individual studies revealed a significant improvement of 
echocardiographic parameters $[15,24]$, the pooled analysis of the available seven noninvasive studies and one invasive trial [24] showed that exercise training was associated with a significant decrease in resting systolic pulmonary artery pressure from baseline to follow-up $(-3.7 \mathrm{mmHg}$; $95 \% \mathrm{CI}-5.4$ to -1.9$)$.

In summary, supervised exercise training may improve right ventricular function and pulmonary haemodynamics in patients with stable PH. Improved haemodynamics may contribute to an increase of exercise capacity and QoL of patients. As invasive data are only available from a single prospective randomised study [24], further investigations are needed to confirm these data.

\section{Muscle function in PH patients}

Leg fatigue and dyspnoea during exercise are the main indications of skeletal muscle dysfunction in patients with PAH [46]. Maximal volitional and nonvolitional strength of both the quadriceps as well as the inspiratory muscles are reduced in PAH patients and are closely correlated to exercise capacity [47-49]. Moreover, on the cellular level, alterations are observed in both the respiratory as well as the peripheral muscles (table 3).

Inspiratory muscle strength largely depends on diaphragm muscle function. Data from $\mathrm{PH}$ rats and $\mathrm{PAH}$ patients suggest that part of the respiratory muscle dysfunction can be explained by a reduction in force generating capacity of the diaphragm muscle fibres [50-52].

Because of inconsistent data in the literature, it is more difficult to define the structural and contractile alterations that would explain the observed peripheral muscle weakness. Muscle fibre size has been reported to be decreased (atrophy) $[53,54]$ or unaltered $[48,50,55,56]$ in PAH patients and PH rats. In addition, a switch to the more fast-twitch fibre type has been reported $[48,53,56]$, but not in all studies $[53,55]$. Similarly, a loss in capillary density in quadriceps muscle of $\mathrm{PAH}$ patients and $\mathrm{PH}$ rats has been reported [55], but could not be confirmed in other studies [34, 54]. Finally, reduced force-generating capacity of quadriceps muscle fibres could only be observed in PAH patients [57], but not in $\mathrm{PH}$ animal models [50-52]; thus, the underlying cause of peripheral muscle weakness is not completely clear, but may involve atrophy, sarcomeric dysfunction, fibre type switch or capillary rarefaction [58].

The lack of standardisation and small sample size of the individual studies are possible explanations for the conflicting findings. In future, larger multicentre studies should be performed to determine the contribution of quadriceps muscle atrophy on reduced skeletal muscle function. In addition, the underlying pathophysiological mechanisms (e.g. physical activity, inflammation, hypoxia, insulin resistance, sympathetic activity, cardiac output) [59] should be investigated in order to generate specific treatment strategies (see section on mechanisms of action). Finally, a direct comparison of quadriceps abnormalities observed in $\mathrm{PAH}$, chronic obstructive pulmonary disease and chronic heart failure would be helpful to assess the specificity of the skeletal muscle dysfunction in PAH patients.

\section{Quadriceps and inspiratory muscle training}

With the inclusion of specific quadriceps and inspiratory muscle training in the exercise training programme, peripheral and inspiratory muscle weakness can be targeted. Quadriceps muscle training and endurance training (cycling) has been shown to be effective in improving quadriceps muscle strength and endurance capacity in PAH patients [21]. In addition, aerobic capacity of the quadriceps muscle fibres improved, characterised by an increased capillary density and oxidative enzyme activity (table 3). A fibre type switch to more oxidative (type 1) muscle fibres has been reported after exercise training in PAH [34].

Inspiratory muscle training has been reported to be beneficial for inspiratory muscle function. In addition, PAH patients report a better QoL and decreased sensation of dyspnoea after inspiratory muscle training [31]. Finally, literature on left heart failure suggests that inspiratory muscle training and exercise training are able to reduce sympathetic drive, potentially leading to improved cardiac function and reduced respiratory drive [60].

\section{Limitations of training studies in $\mathrm{PH}$}

Although an emerging body of data presents beneficial effects of rehabilitation programmes in $\mathrm{PH}$, the findings are limited by several factors. It is a common problem of exercise training studies that they cannot be performed in a blinded design. This may lead to biased results, as patients may decline to participate after randomisation, or may start exercise training by themselves, despite being allocated to the control arm. This bears the risk of unsupervised training, in addition to biased trial results, which hinders the collection of long-term data on control patients. This may be one reason why there are still no long-term data on exercise training and rehabilitation effects in PH. A referral bias cannot be excluded in most studies, since more active and compliant patients may have participated. Consequently, there is a need for 
TABLE 3 Summary of studies analysing muscle function in pulmonary hypertension

\begin{tabular}{|c|c|c|c|c|c|c|}
\hline $\begin{array}{l}\text { First author, year, } \\
\text { [ref.] }\end{array}$ & Type of muscle & $\begin{array}{l}\text { Sample } \\
\text { size } \mathrm{n}\end{array}$ & Patients & $\begin{array}{l}\text { Animal } \\
\text { model }\end{array}$ & Muscle function & Cellular changes \\
\hline Vescovo, 1998 [56] & $\begin{array}{l}\text { Peripheral (M. soleus } \\
+ \text { EDL) }\end{array}$ & $3016 / 14^{\#}$ & & МСТ30 & & $\begin{array}{l}\downarrow \text { fibre type } I / I I \text { ratio } \\
\quad \approx \mathrm{CSA}\end{array}$ \\
\hline MeYER, 2005 [49] & Respiratory & $\begin{array}{c}46 \\
26 / 20^{\#}\end{array}$ & IPAH & & $\downarrow P$ Imax,$P$ Emax & \\
\hline KABITZ, 2008 [47] & Respiratory & $\begin{array}{c}62 \\
31 / 31^{\#}\end{array}$ & $\begin{array}{l}\text { PH (25 PAH, } 6 \\
\text { CTEPH) }\end{array}$ & & $\begin{array}{c}\downarrow P \text { Imax, } P \text { Emax, } \\
\text { Tn } P \text { na, }, \operatorname{Sn} P \text { di, } T w P \text { mo }\end{array}$ & \\
\hline MAINGUY, 2010 [48] & $\begin{array}{l}\text { Peripheral (M. } \\
\text { quadriceps) }\end{array}$ & $\begin{array}{c}20 \\
10 / 10^{\#}\end{array}$ & IPAH & & $\begin{array}{l}\downarrow \text { maximal voluntary contraction } \\
\text { (volitional), quadriceps twitch } \\
\text { (non-volitional) }\end{array}$ & $\begin{array}{c}\downarrow \text { fibre type } 1 / I I \text { ratio, } P F K / H A D H \text { ratio } \\
\approx \text { capillary density, } C S, C S A, H A D H, P F K / C S \\
\text { ratio }\end{array}$ \\
\hline \multirow[t]{2}{*}{ de MAN, 2011 [50] } & $\begin{array}{l}\text { Respiratory } \\
\text { (diaphragm) } \\
\text { Peripheral (EDL or } \\
\text { M. quadriceps) }\end{array}$ & $\begin{array}{c}12 \\
6 / 6^{\#} \\
15 \\
8 / 7^{\#}\end{array}$ & $\mathrm{PH}$ & МСТ60 & $\begin{array}{c}\text { Patient diaphragm: } \\
\downarrow \text { maximal isometric force } \\
\text { Animal model diaphragm: } \\
\text { single muscle fibres: } \downarrow \text { twitch force, } \\
\text { tetanic force, force-frequency }\end{array}$ & $\begin{array}{c}\text { Patients' diaphragm: } \\
\downarrow \text { CSA diaphragm } \\
\approx \text { CSA quadriceps } \\
\text { Animal model diaphragm: } \\
\downarrow \text { CSA } \\
\approx \text { capillary density, SDH, Akt phosphorylation, } \\
\text { MHC expression, } 20 \text { s proteasome, proteasome } \\
\text { activity } \\
\uparrow \text { MAFbx, MuRF-1 }\end{array}$ \\
\hline & & & & & $\begin{array}{l}\text { Peripheral muscle: } \approx \text { twitch force, } \\
\text { tetanic force, force-frequency }\end{array}$ & $\begin{array}{l}\text { Peripheral muscle: } \\
\quad \approx \mathrm{CSA}\end{array}$ \\
\hline MANDERS, 2012 [52] & $\begin{array}{c}\text { Respiratory } \\
\text { (diaphragm) } \\
\text { Peripheral (EDL) }\end{array}$ & $\begin{array}{c}14 \\
7 / 7^{\#}\end{array}$ & & МСТ60 & 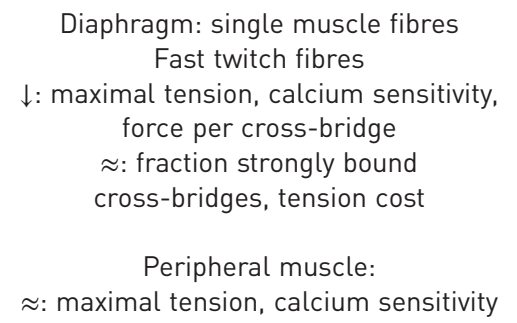 & $\begin{array}{c}\text { Diaphragm } \\
\downarrow \text { : fibre type } \mathrm{I} / \mathrm{II} \text { ratio, nitrosative stress } \\
\approx \text { : oxidative stress }\end{array}$ \\
\hline Wüst, 2012 [54] & $\begin{array}{l}\text { Peripheral (M. } \\
\text { plantaris) }\end{array}$ & $\begin{array}{c}23 \\
11 / 12^{\#}\end{array}$ & & MCT60 & & $\begin{array}{c}\downarrow \text { : CSA, complex I activity, SDH } \\
\approx \text { : fibre type I/II ratio, capillary density }\end{array}$ \\
\hline
\end{tabular}




\begin{tabular}{|c|c|c|c|c|c|c|}
\hline $\begin{array}{l}\text { First author, year, } \\
\text { [ref.] }\end{array}$ & Type of muscle & $\begin{array}{l}\text { Sample } \\
\text { size } n\end{array}$ & Patients & $\begin{array}{c}\text { Animal } \\
\text { model }\end{array}$ & Muscle function & Cellular changes \\
\hline ВАTT, 2014 [53] & $\begin{array}{l}\text { Peripheral (M. } \\
\text { quadriceps) }\end{array}$ & $\begin{array}{c}20 \\
10 / 10^{\#}\end{array}$ & $\begin{array}{l}\text { PAH (IPAH + PAH } \\
1 \text { year after ASD } \\
\text { repair) }\end{array}$ & & & $\begin{array}{c}\text { Overall } \\
\downarrow \text { : CSA, fibre type I/II ratio } \\
\text { Regulators muscle mass } \\
\downarrow: \text { pAkt, p-p70S6kinase, pFOXO } 3 \\
\approx: \text { pGSK3 } \beta \\
\uparrow: \text { Atrogin-1, MuRF1 } \\
\text { Mitochondrial fusion } \\
\downarrow: \text { Mitofusin } 1 \text { and } 2 ; \approx \text { : DRP } \\
\text { Mitochondrial biogenesis } \\
\approx: \text { PGC } 1 \alpha, \text { MtCO }_{2}, \text { NRF-1, TFA } \\
\text { Calcium cycling } \\
\uparrow: \text { pRyR } \\
\approx: \text { SERCA2a, SERCA }\end{array}$ \\
\hline Potus, 2014 [55] & $\begin{array}{l}\text { Peripheral (M. } \\
\text { quadriceps) }\end{array}$ & $\begin{array}{c}40 \\
20 / 20^{\#}\end{array}$ & $\begin{array}{l}\text { PAH (16 IPAH, } 4 \\
\text { HPAH) }\end{array}$ & & $\downarrow:$ quadriceps endurance & $\begin{array}{c}\downarrow \text { : ERK activity, capillary density, miR-126, RAF } \\
\text { activity } \\
\begin{array}{c}\approx \text { : CSA, fibre type I/II ratio, VEGF, VEGFR2 } \\
\uparrow: \text { SPRED-1 }\end{array}\end{array}$ \\
\hline MANDERS, 2015 [57] & $\begin{array}{l}\text { Peripheral (M. } \\
\text { quadriceps) }\end{array}$ & $\begin{array}{c}19 \\
11 / 8^{\#}\end{array}$ & IPAH & & $\begin{array}{c}\text { Single muscle fibres: } \\
\downarrow \text { : maximal tension, number of attached } \\
\text { cross-bridges during activation } \\
\approx \text { : fraction strongly bound } \\
\text { cross-bridges, force per cross-bridge, } \\
\text { calcium sensitivity } \\
\uparrow: \text { passive stiffness }\end{array}$ & \\
\hline MANDERS, 2016 [51] & $\begin{array}{l}\text { Respiratory } \\
\text { (diaphragm) }\end{array}$ & $\begin{array}{c}28 \\
13 / 15^{\#}\end{array}$ & CTEPH & & $\begin{array}{c}\text { Single muscle fibres: } \\
\text { Slow-twitch fibres: } \\
\downarrow: \text { maximal tension, number of attached } \\
\text { cross-bridges during activation } \\
\text { Fast-twitch fibres: } \\
\downarrow: \text { calcium sensitivity, submaximal } \\
\text { tension } \\
\approx \text { : force per cross-bridge }\end{array}$ & $\begin{array}{c}\downarrow: \text { MHC concentration (slow-twitch fibres) } \\
\quad \approx: \text { CSA }\end{array}$ \\
\hline
\end{tabular}

$\downarrow$ : reduction; $\uparrow:$ increase; $\approx$ : no change; EDL: extensor digitorum longus (peripheral muscle); MCT: monocrotaline; CSA: cross-sectional area; IPAH: idiopathic pulmonary arterial hypertension; PImax (volitional): maximal inspiratory mouth pressure; PEmax (volitional): expiratory mouth pressure; PH: pulmonary hypertension; PAH: pulmonary arterial hypertension; CTEPH: chronic thromboembolic pulmonary hypertension; $\mathrm{SnP}$ na (volitional): sniff nasal pressure; SnPdi (volitional): sniff transdiaphragmatic pressure; TwPmo (non-volitional): twitch mouth pressure; TwPdi (non-volitional): transdiaphragmatic pressure; PFK/HADH: $\beta$-oxidation of fatty acids; CS: citrate synthase; HADH: 3-hydroxyacyl-coA-dehydrogenase; PFK/CS: glycolysis to citric acid cycle; SDH: succinate dehydrogenase loxidative enzyme activity); Akt: protein kinase B; MHC: myosin heavy chain; MAFbx/MuRF-1: E3-ligases; MuRF: muscle RING-finger protein; ASD: atrial septum defect; DRP: dynamin-related protein; PGC1 $\alpha$ : peroxisome proliferator-activated receptor- $\gamma$ coactivator; GSK3 $\beta$ : glycogen synthase kinase $3 \beta$; MtCO2: mitochondrial encoded cytochrome C oxidase subunit II: NRF-1: nuclear respiratory factor 1; RyR: ryanodine receptor; SERCA: sarco/endoplasmic reticulum Ca ${ }^{2+}$-ATPase; HPAH: hereditary PAH; ERK: extracellular signal-regulated kinase; miR-126: microRNA126; VEGF: vascular endothelial growth factor; VEGFR2: VEGF receptor type 2; SPRED1: Sprouty-related EVH1 domain-containing protein 1. ": for numbers displayed as " $x / y$ ", $x$ is number of patients, $y$ is number of controls. 
trial designs that address these issues, such as the offer to participate in training after the control phase or the use of Zelen's design.

As $\mathrm{PH}$ is a rare disease, many studies included different subgroups of $\mathrm{PH}$ such as PAH and CTEPH. Training effects are generally described in the preceding paragraphs, but need to be investigated and distinguished between different types of $\mathrm{PH}$ in the future.

While the effects of exercise rehabilitation in $\mathrm{PH}$ have been investigated and shown to be beneficial as primary end-points for most outcomes $\left(6 \mathrm{MWD}\right.$, peak $V^{\prime} \mathrm{O}_{2}$, QoL, blood flow of the lung, peak muscle power), the presented randomised controlled trials are of varying quality [42] and require further validation. Most of the data about training effects in $\mathrm{PH}$ rely on results from a single centre, which offered a rather intensive beginning to the exercise training programme. An intensive in-hospital programme demands substantial personnel, time and money resources and may therefore not be widely available. Future research should be based on larger-scale multicentre studies for external validity of the data.

\section{Future directions: challenges and research questions}

Since the publication of the European Society of Cardiology (ESC)/ERS guidelines, two further randomised controlled trials $[24,26]$ and several meta-analyses have been published [39-42] that confirm the positive effect of training in $\mathrm{PH}$. However, the current data do not provide any conclusion about the effects of exercise training on different types of $\mathrm{PH}$, which should be stratified and analysed in future studies.

The large body of evidence presented in the preceding sections may influence the grading of exercise training in the next guideline recommendations. Nevertheless, multicentre studies involving $\mathrm{PH}$ expert centres are needed to assess the effect of exercise training in different countries with different healthcare systems to clarify whether this therapy can be widely used in $\mathrm{PH}$ patients.

Methodological aspects such as patient selection, optimal training methods as well as external validation of trial results should also be addressed in future trials. A current multicentre randomised controlled trial aims to gain further insights into the efficacy, safety and external validity of exercise training in $\mathrm{PH}$. Current findings on these issues will be displayed in more detail later on.

Within the last decades, clinical trial end-points in $\mathrm{PH}$ studies have evolved from the primary end-point exercise capacity (6MWD) to event-driven time to clinical worsening outcomes. In this regard, a need of studies investigating the effect of exercise training on disease progression and survival has been pointed out [61, 62]. While the safety and beneficial outcome effects of exercise-based rehabilitation have been demonstrated in other disease areas such as left heart failure and cancer [10, 63, 64], few data are available addressing the potential impact of exercise training on disease progression or survival in $\mathrm{PH}$ [42].

Determining the effect of a dedicated exercise programme in $\mathrm{PH}$ is complicated by many factors. For example, the type of $\mathrm{PH}$ itself can have a significant impact on disease progression and patient survival. To determine the impact of any intervention in $\mathrm{PH}$ we need clinically relevant and robust end-points. While traditionally the 6MWD has been used in drug development it has many limitations, most particularly in the study of exercise effects. Similarly, while cardiopulmonary exercise testing (CPET) parameters do predict survival in $\mathrm{PH}$ patients, they only add marginally to the prognostic value of the 6MWD [65]. So, while improvements in 6MWD, peak $V^{\prime} \mathrm{O}_{2}$, muscle strength and endurance, as well as physical and mental QoL (SF-36 questionnaire) have been demonstrated in response to exercise rehabilitation in $\mathrm{PH}$, their impact on disease progression or as disease modifiers have not yet been shown in randomised, controlled studies. Moreover, a more PH-specific QoL questionnaire as a patient-reported outcome measure such as the Cambridge Pulmonary Hypertension Outcome Review (CAMPHOR), the emPHasis-10 or the PAH-Symptoms and Impact Questionnaire (PAH-SYMPACT) might provide even better insights into the impact of exercise training than the generic SF-36, which has already shown significant improvements in various subscales.

Randomised controlled trials investigating the effect of exercise training on disease progression and survival are still lacking. One single prospective study with a retrospective control group detected a significantly better survival and less worsening events of the training group, compared to patients who were treated with targeted medication only $(\mathrm{p}=0.005)$ [30]. An association between activity level and outcome was demonstrated in a cohort study of 23 patients with $\mathrm{PAH}$ or CTEPH who showed a significantly lower survival, when being active for $<15 \mathrm{~h} \cdot \mathrm{day}^{-1}(\mathrm{p}=0.026)$ [66]. A composite morbidity and mortality end-point has been used recently in drug development and has highlighted that disease progression is frequently marked by hospitalisation. However, morbidity and mortality studies need large numbers of patients and prolonged monitoring to determine if disease progression has been affected. This is warranted, but difficult to reach, especially in studies analysing effects of exercise training as an add-on to optimised medical 
treatment. There is no funding for such large trials and currently there are not enough rehabilitation/PAH centres experienced with this treatment to reach high patient numbers. Furthermore, patients who participate in such studies mostly want to receive the exercise training within a reasonably short time period. The next step to reach such studies could be to standardise the $\mathrm{PH}$-specialised rehabilitation programme in different European countries and to establish more centres that could offer this treatment to patients in such long-scaled studies in the future. Changes in ERS/ESC risk classification could act as a possible surrogate to assess the effect of exercise rehabilitation on disease progression and survival. Whether the impact of new therapies, including dedicated exercise programmes, can modify the risk profile in $\mathrm{PAH}$ and impact on disease progression and survival remains to be determined.

In summary, there is no direct evidence for an impact of exercise training on survival and outcome in $\mathrm{PH}$. However, several studies suggest a beneficial effect on prognostically important parameters. Studies with survival and time to clinical worsening as the primary outcome are hindered by ethical and methodological aspects. A future approach to this question could be to investigate the impact of exercise training on risk profiles in $\mathrm{PH}$.

\section{Part II: training modalities and setting}

There have been different approaches in training modalities across countries and rehabilitation programmes. Exercise training was either started in hospital and subsequently performed at home, or was implemented as an entire outpatient programme. A thorough monitoring and supervision by $\mathrm{PH}$ centres of the exercise training was performed in all training studies. A summary of the different training set-ups is given in table 4 .

\section{Setting and outcome measures \\ In-hospital start of exercise training}

Most of the subjects studied $(\mathrm{n}=519)$ participated in the "Heidelberg" training programme that started with an in-hospital stay for 3 weeks followed by a second ambulatory part continuing exercise training [15-20, 24, 30, 31]. The initial in-hospital training allowed close supervision of exercise by physiotherapists, with heart rate and oxygen saturation monitoring [67]. Up-titration of exercises and prescription of oxygen was performed based on predefined saturation and heart rate safety parameters (table 4 ).

\section{Outpatient programmes}

As inpatient settings are not available in all healthcare systems, several outpatient programmes have been investigated and results have been published so far from $176 \mathrm{PH}$ patients (table 4) [21-23, 26-28, 34-36, 38]. Outpatient programmes typically use two to three supervised sessions per week in hospital rooms for $\sim 12$ weeks. In addition, there have been two small studies $(n=25)$ looking at solely home-based exercise programmes $[32,33]$. A wide range of training frequencies has been used, between two to five times per week, with different total duration of training units in the programme/training day and with duration of the study lasting from 6 weeks to 1 year.

The majority of studies have demonstrated clinical benefits (tables 1 and 2). 30\% of the studies did not show an improvement in 6MWD, but reported improvement in other parameters such as muscle strength and endurance exercise capacity [21] or QoL scores [33].

Members of the multidisciplinary team

The involvement of a physiotherapist has been a constant feature in all studies involving exercise programmes. They are thought to be crucial to the delivery of the programme and can also provide support in other aspects, such as mobility, practical advice regarding activities of daily living, psychological support and relaxation therapies [15].

Additionally, involvement of the medical team with $\mathrm{PH}$ expertise in the development and delivery of the exercise programme has been a feature of all previous studies. In-hospital programmes take place in $\mathrm{PH}$ centres with multidisciplinary teams consisting of psychologists, $\mathrm{PH}$ nurse specialists and dieticians (table 5; for more details, refer to the section on Requirements of different healthcare systems). A multidisciplinary (physiatrist, cardiologist, pulmonologist) and multiprofessional (exercise physiologist, physical therapist, nurse, psychologist, dietician) approach offers to address different aspects of the disease during the intervention. As anxiety and depression show an increasing prevalence with higher WHO functional class, psychological counselling may often support the patients' wellbeing.

Training components and intensity

The rehabilitation programmes for severe chronic $\mathrm{PH}$ patients consist of a diverse array of training components (table 6). The resistance training mainly consisted of dumbbell training of distinct muscle 


\begin{tabular}{|c|c|c|c|c|}
\hline First author, year [ref.] & Patients ${ }^{\#} \mathbf{n}$ & Frequency of training & Length of programme & Monitoring \\
\hline Inpatient & $511 / 560^{\#}$ & & & \\
\hline MeReLES, 2006 [15] & $15 / 15^{\text {ๆ }}$ & 7 days per week & 15 weeks & Subjective physical exertion HR $<120$ beats $\cdot \mathrm{min}^{-1}$ \\
\hline GRÜNIG, $2011[20]$ & 58 & & Weeks $1-3$ inpatient & $\mathrm{SaO}_{2}>85 \%$ (if lower, supplemental oxygen supplied) \\
\hline BECKER-GRÜNIG, 2013 [16] & 20 & & Weeks $4-15$ at home & \\
\hline EHLKEN, 2014 [30] & $58^{+}$ & & & \\
\hline LEY, 2013 [25] & $10 / 10^{9}$ & & 3 weeks inpatient & \\
\hline GRÜNIG, 2012 [18] & 21 & & 15 weeks & See MereLES et al. [15] \\
\hline GRÜNIG, 2012 [19] & 183 & & Weeks $1-3$ inpatient & Supplemental oxygen if $\mathrm{SaO}_{2}<90 \%$ \\
\hline$N_{A G E L} 2012[17]$ & 35 & & Weeks $4-15$ at home & \\
\hline EHLKEN, 2016 [24] & 87 & & & \\
\hline \multirow[t]{3}{*}{ KABITZ, 2014 [31] } & 7 & & & See Mereles et al. [15] \\
\hline & & & & $\mathrm{HR} \leqslant 130$ beats $\cdot \mathrm{min}^{-1}$ \\
\hline & & & & Supplemental oxygen if $\mathrm{SaO}_{2}<90 \%$ \\
\hline \multirow[t]{3}{*}{ FuKUI, 2016 [29] } & $17 / 24^{9}$ & 7 days in first week & 12 weeks & Borg scale 12-13 (scale 6/20) \\
\hline & & $\sim 4$ days per week $2-12$ & Week 1 in hospital Weeks & HR $40-60 \%$ of HR reserve \\
\hline & & & $2-12$ at home & $\mathrm{SaO}_{2} \geqslant 90 \%$ \\
\hline Outpatient & $138 / 176^{\#}$ & & & \\
\hline SHOEMAKER, 2009 [35] & 2 & 3 days per week & 6 weeks & $\begin{array}{l}\text { Subjective exertion }<4 / 10, \mathrm{HR} \leqslant 80 \% \text { age-predicted } \\
\text { maximum, blood pressure } \leqslant 180 \mathrm{mmHg}, \mathrm{SaO}_{2}>91 \%\end{array}$ \\
\hline DE MAN, 2009 [21] & 19 & 3 days per week & 12 weeks & $\begin{array}{c}\mathrm{SaO}_{2}>85 \% \\
\mathrm{HR}<120 \text { beats } \cdot \mathrm{min}^{-1}\end{array}$ \\
\hline MARTÍNEZ-QuintANA, 2010 [28] & $4 / 4^{\pi}$ & 2 days per week & 12 weeks & Borg scale, HR \\
\hline MaINGUY, $2010[34]$ & 5 & 3 days per week & 12 weeks & Borg scale $<6 / 10$ \\
\hline & & & & Resting allowed \\
\hline Fox, $2011[27]$ & $11 / 11^{\pi}$ & 2 days per week & 12 weeks & $\begin{array}{c}\text { Intensity reduced if } \mathrm{SaO}_{2}<85 \% \\
\text { Subjective exertion, rest permitted, } \mathrm{HR}, \mathrm{SaO}_{2} \text { "monitored" } \\
\mathrm{SaO}_{2}>90 \% \text { (if lower, supplemental oxygen supplied) }\end{array}$ \\
\hline CHAN, 2013 [22] & $10 / 13^{\pi}$ & 3 days per week & 10 weeks & Subjective exertion, $\mathrm{SaO}_{2}, \mathrm{HR}$ "monitored" (no values given) \\
\hline WeINSTEIN, 2013 [23] & $11 / 13^{9}$ & 3 days per week & 10 weeks & Subjective exertion, $\mathrm{SaO}_{2}, \mathrm{HR}$ "monitored" (no values given) \\
\hline RASKIN, 2014 [37] & 23 & 2-3 days per week & $>8$ weeks & Borg scale \\
\hline GonZÁLEZ-SAIZ, 2017 [26] & $20 / 20^{\pi}$ & 3 days per week & 8 weeks & $\mathrm{SaO}_{2}>80 \%$ \\
\hline & & & & $\mathrm{BP}$ reduction $<20 \mathrm{mmHg}$ \\
\hline & & & & $\begin{array}{c}\text { BP systolic }<220 \mathrm{mmHg} \text {, diastolic }<110 \mathrm{mmHg} \\
\text { No ECG abnormalities }\end{array}$ \\
\hline TALWAR, 2017 [38] & 18 & 3 days per week & 12 weeks & $\begin{array}{l}\text { Only safety equipment specified (blood pressure monitor, } \\
\text { ECG, pulse oximetry, supplemental oxygen) }\end{array}$ \\
\hline Bussottı, 2017 [36] & 15 & 5 days per week & 4 weeks & $\mathrm{HR}<70 \%$ of max at CPET \\
\hline & & & & Borg scale $<5$ \\
\hline & & & & $\mathrm{SaO}_{2}>90 \%$ \\
\hline Home & 25 & & & \\
\hline INAGAKI, 2014 [32] & 8 & $\begin{array}{l}1 \text { hospital session per week } \\
\text { and } 3 \text { sessions at home per week }\end{array}$ & 12 weeks & Subjective exertion \\
\hline IHLE, 2014 [33] & 17 & 1 day per month & 40 weeks & $\begin{array}{l}\text { Subjective exertion: Borg scale }<7 / 10 \\
\mathrm{HR} \text { increase }<30 \text { beats } \cdot \mathrm{min}^{-1} \mathrm{SaO}_{2}>85 \%\end{array}$ \\
\hline
\end{tabular}


TABLE 5 Components of multidisciplinary settings

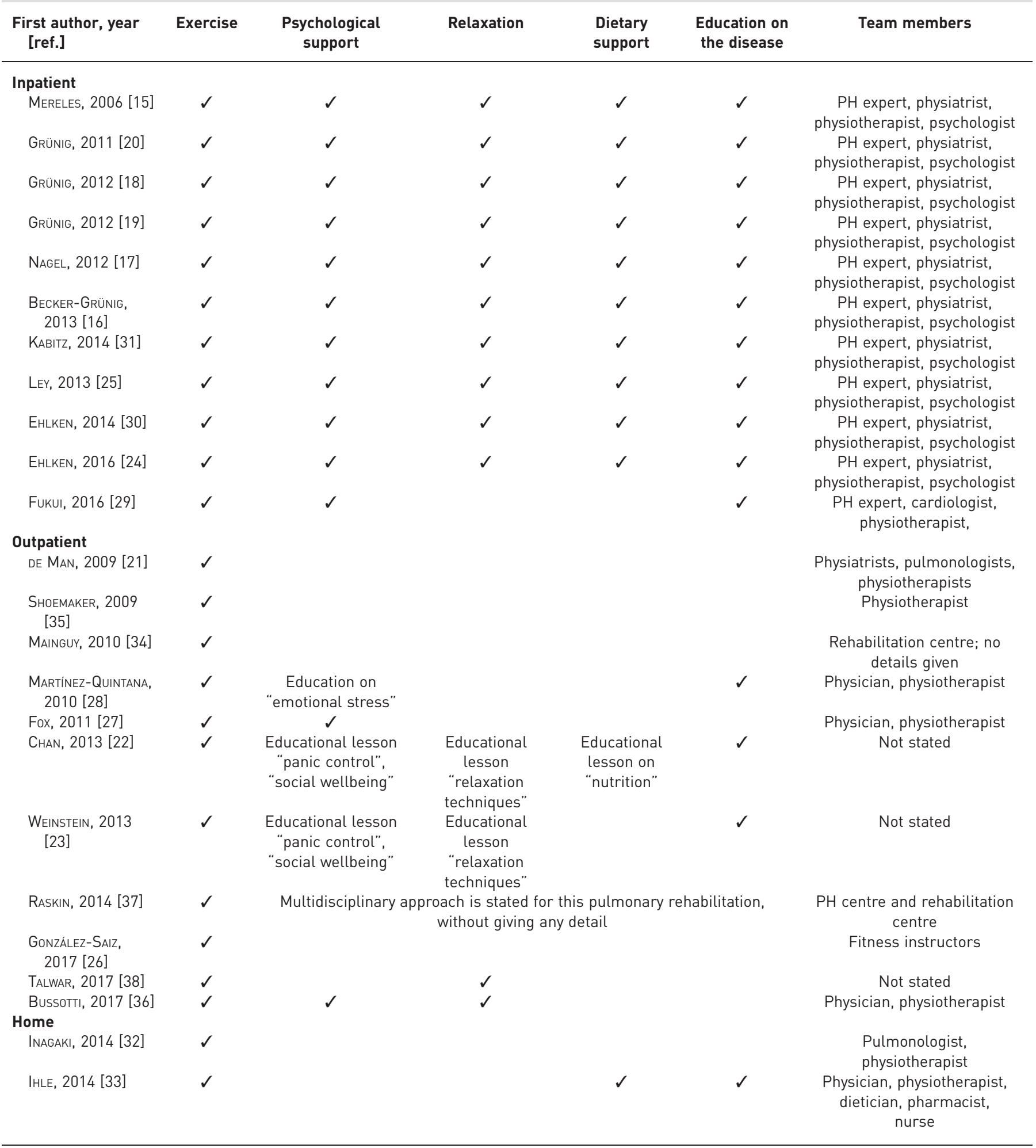

$\mathrm{PH}:$ pulmonary hypertension.

groups. Aerobic training is conducted in form of ergometer training, treadmill walking or cross-trainer exercises [68].

For the studies based on an initial inpatient phase performed in Germany, exercise training was complemented by mental gait training and guided walks. The mental gait training was introduced to the 
TABLE 6 Training modalities and intensities in exercise training studies

$\begin{array}{llll}\text { First author, year [ref.] } & \begin{array}{c}\text { Country (city or } \\ \text { state) }\end{array} & \text { Exercise training modalities } & \text { Training intensity }\end{array}$

\begin{tabular}{|c|c|c|c|}
\hline $\begin{array}{l}\text { MereLEs, 2006 [15] } \\
\text { Ley, } 2013 \text { [25] }\end{array}$ & $\begin{array}{l}\text { Germany } \\
\text { (Heidelberg) }\end{array}$ & $\begin{array}{l}\text { Bicycle ergometer, interval (1 } \mathrm{min} \text { high/30 s low; } 10-25 \mathrm{~min} \text { ), } \\
\quad 10-60 \mathrm{~W} \\
\text { Walking/mental gait training (60 } \mathrm{min})\end{array}$ & $\begin{array}{l}60-80 \% \text { peak } \mathrm{V}^{\prime} \mathrm{O}_{2}[15,25] \\
\text { progressive increase } \\
\text { during programme }\end{array}$ \\
\hline GRÜNIG, 2011 [20] & & Resistance exercise; low-weight dumbbell training or & $10-60$ W $[16-20,30,31]$ \\
\hline GRÜNIG, 2012 [19] & & strength training (30 min) & progressive increase \\
\hline GRÜNIG, 2012 [18] & & Respiratory muscle training (30 min) & during programme \\
\hline NAGEL, 2012 [17] & & Frequency: each training item $\geqslant 5$ times per week & \\
\hline
\end{tabular}

MainguY, 2010 [34] Canada (Québec)

BECKER-GRÜNIG, 2013 [16]

KABITZ, 2014 [31]

EHLKEN, 2014 [30]

EHLKEN, 2016 [24]

IHLE, 2014 [33]

Fox, $2011[27]$

Bussottı, 2017 [36]

INAGAKI, 2014 [32]

FukU1, 2016 [29]

DE MAN, 2009 [21]

Martinez-Quintana, 2010
[28]
Israel (Tel Aviv)

Italy (Milan)

Japan (Chiba)

Japan (Suita)

Netherlands (Amsterdam)

Spain (Las Palmas de Gran Canarial
Frequency: each training item $\geqslant 5$ times per week

Breathing exercise (30 min)

Resistance exercise/moderate endurance training of leg muscle $(30 \mathrm{~min}) 3$ sets of 5 repetitions, stretching, motion exercises

Educational training (30 $\mathrm{min}$ )

Frequency: in-hospital once per month

Bicycle ergometer, continuous (10-15 min)

Brisk treadmill walking (15 min)

Resistance exercise, 2 sets $10-12$ repetitions of $6-8$ single muscle group exercises

Frequency: 3 times per week

Weeks 1-6: treadmill walking/cycling/step climbing, interval (60 min)

Weeks 7-12: resistance exercise llow-weight dumbbell training or strength training)/aerobic training, continuous (60 min total)

Frequency: twice per week

Bicycle ergometer, continuous (30 min)

Resistance exercise, 10-15 repetitions of weight lifting $(0.5-1 \mathrm{~kg})$

Respiratory muscle training ( $10 \mathrm{~min}$ up to $30 \mathrm{~min}$ )

Slow breathing sessions (25-30 min)

Educational lessons

Frequency: 5 times per week

Walking, continuous (>20 min)

Resistance training, 1-3 sets with 10-15 repetitions

Respiratory exercise ( 20 min)

Frequency: in-hospital once per week

Walking (30-60 min)

Bicycle ergometer

Resistance training (low weights)

Frequency: week 1 daily, weeks 2-12 outpatient session twice per week

Cycling, interval (35-40 min)

Weeks 1-3: $2 \min 50 \% V^{\prime} \mathrm{O}_{2} \max , 2$ min rest

Weeks 4-6: 3 min 50\% $V^{\prime} \mathrm{O}_{2}$ max, 2 min rest

Weeks 7-9: $4 \min 75 \% V^{\prime} \mathrm{O}_{2}$ max, 2 min rest

Weeks 10-12: 5 min $75 \% V^{\prime} \mathrm{O}_{2} \max , 2$ min rest

Quadriceps strength; endurance ( $20 \mathrm{~min}$ )

Weeks 1-3: strength 50\% ORM, endurance 30\% ORM

Weeks 4-6: strength 50\% ORM, endurance 30\% ORM

Weeks 7-9: strength 75\% ORM, endurance 40\% ORM

Weeks 10-12: strength 75\% ORM, endurance 40\% ORM

Frequency: three times per week

Warm up: stretching/resistance exercise with 1-2 kg (10 min)

Bicycle ergometer, interval: $30 \mathrm{~s}$ high at $20-50 \mathrm{~W} / 30 \mathrm{~s}$ low at 10-25 W (24 min)

Educational lessons (time not specified)

Frequency: twice per week
$10-60 \mathrm{~W}$

$60 \%$ max workload

$85 \%$ mean speed during 6MWT

$70 \%$ max voluntary contraction

60-80\% HR at peak $V^{\prime} \mathrm{O}_{2}$

$50 \%$ peak workload

60\% max HR

Free from/minor subjective dyspnoea

40-60\% HR reserve

$75 \% \mathrm{~V}^{\prime} \mathrm{O}_{2} \max$

$\%$ of maximum repetition on 1st day

$80 \%$ max HR during 6MWT Borg scale 3-6 
TABLE 6 Continued

First author, year [ref.]

statel

GonzÁlez-SAIZ, 2017 [26] Spain (Madrid)

SHOEMAKER, 2009 [35]

USA (Michigan)

TALWAR, 2017 [38]

USA (New York)

RASKIN, 2014 [37]

Weinstein, 2013 [23]

Chan, 2013 [22]
Exercise training modalities

Training intensity

$50 \%$ power output at anaerobic threshold

Against $40 \%$ inspiratory pressure max

Inspiratory muscle training (30 breaths)

Frequency:

Aerobic: 5 times per week

Resistance: 3 times per week

Inspiratory: 6 times per week

Bicycle ergometer, continuous (45 min) 50\% peak workload

Frequency: 3 times per week

Treadmill walking, continuous (20-30 min)

Educational lessons

Frequency: 3 times per week

Aerobic training (treadmill, bicycle, and cross-trainer exercises), continuous (30-60 $\mathrm{min}$ )

Frequency: 2-3 times per week

Treadmill walking, continuous (30-45 min)

Educational lessons (60 min)

Frequency: $\geqslant 2$ times per week
Based on maximal speed and time on a treadmill measured at baseline

Borg scale, "moderate intensity"

$70-80 \%$ max intensity $70-80 \%$ max HR

$\mathrm{V}^{\prime} \mathrm{O}_{2}$ : oxygen uptake; 6MWT: 6-min walk test; $\mathrm{HR}$ : heart rate; ORM: one-repetition maximum. ${ }^{\#}$ : this study refers to the same patients as GRÜNIG [20].

patients in order to improve the estimation of their physical abilities and limitations. Training intensity was adjusted daily to the individual strengths and limitations. Oxygen supply was given according to patient's indication and needs. In general, training intensity was low, $\sim 50 \%$ of peak workload or $\sim 60 \%$ of maximal workload, and carefully monitored as patients were already severely compromised. Aerobic training was mainly conducted at $60-80 \%$ of peak heart rate (table 6). Data for 519 patients are available for exercise training at $\sim 60 \%$ of peak heart rate, not exceeding 120 beats.min ${ }^{-1}$, with an oxygen saturation greater than $85-90 \%$ [68]. Additional respiratory training was performed in the inpatient studies in Germany, one outpatient based study in Italy [36] and one home-based study in Japan [32]. This training component was aimed at strengthening the respiratory muscles and to increase the awareness of different breathing patterns and techniques [69]. Outpatient programmes often included patient education and lectures to learn more about topics such as disease pathophysiology, behaviour in demanding situations and nutrition [23].

\section{Monitoring}

For monitoring, supervision and adjustment of the training intensity, oxygen saturation (>85-90\%), heart rate $\left(<120-130\right.$ beats $\left.\cdot \mathrm{min}^{-1}\right)$ and subjective perception of exertion by Borg dyspnoea score were used. An oxygen desaturation of $<85-90 \%$ or heart rate of $>120$ beats $\mathrm{min}^{-1}$ were mainly used as limiting criteria to adjust training intensity, leading to a short interruption or intensity reduction of the training (compare table 4). The intensity, in particular of the aerobic training, was either individually adjusted on a day-to-day basis or followed a set increase during the course of the training [21, 68]. While all studies monitored the patients closely, the in-hospital programmes had the advantage of giving the patients time to learn the exercises under close supervision with an emphasis on avoiding overexertion.

In conclusion, different training modalities have been investigated in patients with $\mathrm{PH}$. The common features of these programmes are a multidisciplinary approach, close supervision and monitoring, combinations of low-to-moderate intensity endurance, strength and breathing exercises and an assessment of functional aspects and muscular strength, as well as QoL and laboratory parameters. Future studies should be aimed at direct comparisons of training modalities to find out the most advantageous training properties. Furthermore, the components of the multidisciplinary setting should be defined and investigated upon their impact. 
TABLE 7 Outcome measures for training programmes

\begin{tabular}{|c|c|c|c|c|c|c|c|c|c|}
\hline \multirow[t]{2}{*}{ First author, year [ref] } & \multicolumn{3}{|c|}{ QoL\# } & \multicolumn{4}{|c|}{ Functional ability } & \multirow{2}{*}{$\begin{array}{l}\text { Peripheral } \\
\text { muscle } \\
\text { function } \\
\text { Muscle } \\
\text { strength }\end{array}$} & \multirow{2}{*}{$\begin{array}{l}\text { Biomarkers } \\
\text { (NT-pro)-BNP }\end{array}$} \\
\hline & SF-36 & CAMPHOR & $\begin{array}{c}\text { Other } \\
\text { questionnaire }\end{array}$ & 6MWD & $\begin{array}{l}\text { Peak } \\
\mathrm{VO}_{2}\end{array}$ & $\begin{array}{c}\text { Endurance } \begin{array}{c}\text { WHO } \\
\text { functional } \\
\text { class }\end{array} \\
\text { clas }\end{array}$ & $\begin{array}{l}\text { Treadmill } \\
\text { speed }\end{array}$ & & \\
\hline
\end{tabular}

\section{In-patient}

MereLEs, 2006 [15]

GRÜNIG, 2011 [20]

GRÜNIG, 2012 [18]

GRÜNIG, 2012 [19]

NAGEL, 2012 [17]

BECKER-GRÜNIG,

2013 [16]

LEY, 2013 [25]

EHLKEN, 2014 [30]凡

KABITZ, 2014 [31]

EHLKEN, 2016 [24]

FukUI, 2016 [29]

\section{Outpatient}
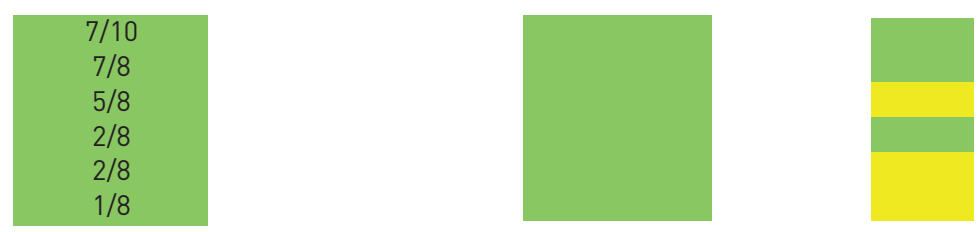

DE MAN 2009 [21]

MartineZ-QuintANA, 2010 [28] SF-12: 0/2

MAINGUY, 2010 [34]

Fox, 2011 [27]

CHAN, 2013 [22]

WEINSTEIN, 2013 [23]

RASKIN, 2014 [37]

ZöLLER, 2017 [43]

GERHARDT, 2017 [44]

TALWAR, 2017 [38]

BussotTI, 2017 [36]

González-SAIZ, 2017 [26]

\section{Home}

INAGAKI, 2014 [32]

IHLE, 2014 [33]
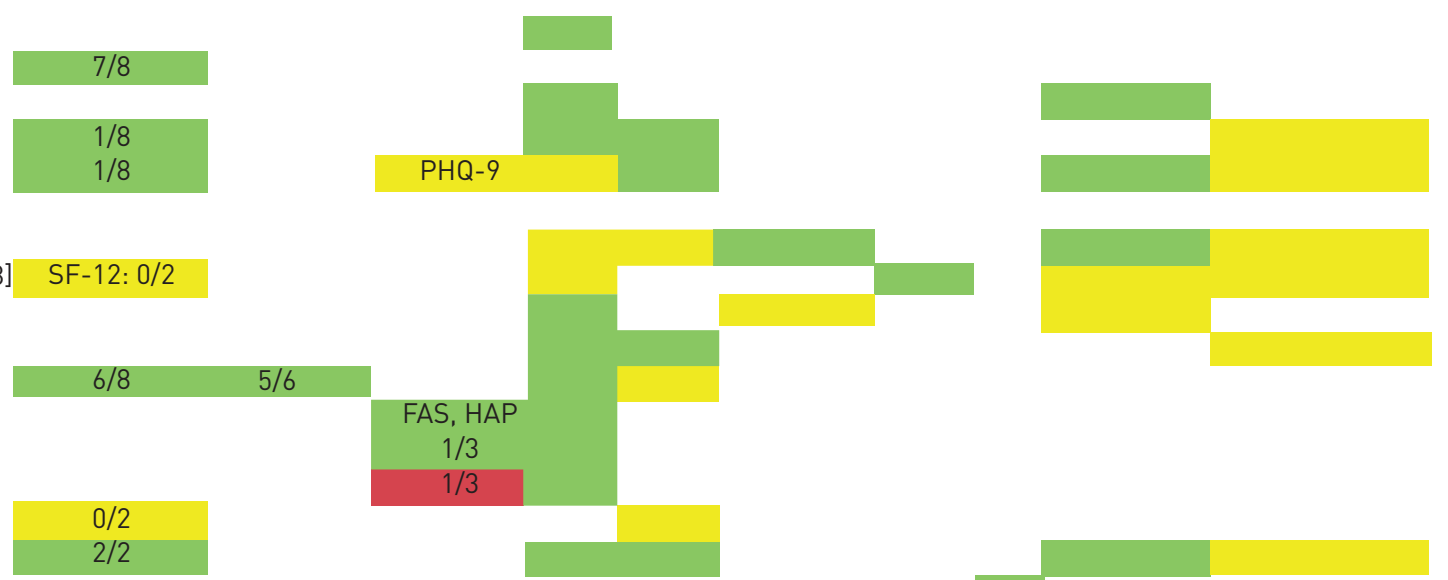

Statistically significant improvement

No significant improvement

Statistically significant deterioration

QoL: quality of life; SF-36: 36-item short-form health survey; CAMPHOR: Cambridge Pulmonary Hypertension Outcome Review; 6MWD: 6-min walk distance; $\mathrm{V}^{\prime} \mathrm{O}_{2}$ : oxygen uptake; WHO: World Health Organization; NT-proBNP: N-terminal pro-brain natriuretic peptide; PHQ-9: Patient Health Questionnaire-9; SF-12: 12-item short-form health survey; FAS: Fatigue Assessment Scale; HAP: Human Activity Profile; HADS: Hospital Anxiety and Depression Scale; EQ-5D: EuroQoL-5 dimensions; SGRQ: St George's Respiratory Questionnaire. \#: the number of subscales with significant improvement/number of tested subscales is given; the numbers given for the SF-36 are in reference to the analysed scales, as follows 10: all subscales and two summation scales, 8: all subscales, 2: two summation scales; detailed results of specific subscales of QoL assessments are presented in table 2. ๆ: this study refers to the same patients as GRüNIG et al. [20].

\section{Outcome measures}

Outcome measures used to assess the efficacy of exercise training in $\mathrm{PH}$ can be broadly split into six categories: symptoms, QoL, pulmonary artery haemodynamics, exercise capacity, peripheral muscle strength and biomarkers (table 7).

In $\mathrm{PH}$, exercise capacity plays a major role, both as a prognostic factor and as a factor strongly associated with QoL. There are many ways to assess exercise capacity. The most commonly applied tests are the 6-min walk test (6MWT) and the shuttle walk test. However, the most comprehensive test is CPET. The ESC/ERS guidelines recommend CPET for patients with $\mathrm{PH}$ not only for decision making concerning therapy, but also because it shows a typical pattern in patients with $\mathrm{PH}$ and thus may serve for early 
diagnosis and differential diagnosis [1]. The highlighted prognostic factors are peak oxygen uptake $\left(V^{\prime} \mathrm{O}_{2}\right)$ $[70,71]$ and the relationship of minute ventilation to carbon dioxide production. For example, a randomised controlled study from Germany showed htat peak $V^{\prime} \mathrm{O}_{2}$ can be used to monitor training effects in $\mathrm{PH}$ [24].

In addition to peak $V^{\prime} \mathrm{O}_{2}$, a second independent prognosticator, the capability of the patient to increase right ventricular systolic pressure by $>30 \mathrm{mmHg}$ even during low-level exercise has been identified [72]. Of note, this finding was valid only in patients with severe PH. In addition, a study from Sheffield (UK) analysing the shuttle walk test found that an inadequate heart rate response was associated with mortality [73]. They concluded that the shuttle walk test was easy to perform and sensitive to the effects of therapy. In comparison to the 6-min walk test, there is no ceiling effect.

In conclusion, exercise tests are important prognosticators in $\mathrm{PH}$ patients and are thus valuable tools to assess effects of training. A low peak $V^{\prime} \mathrm{O}_{2}$, a high pulmonary vascular resistance, a decreased heart rate response during exercise and a lowered blood pressure response to exercise appear as independent prognostic factors. Additional stress echocardiography may reveal an additional independent prognosticator, the right ventricular systolic pressure response to exercise. As training improves both peak $V^{\prime} \mathrm{O}_{2}$ and the heart rate response to exercise, it can be speculated that it may also improve survival, although such studies may not be conducted due to ethical reasons (see the Future directions section).

\section{Safety}

Extensive physical activity may increase pulmonary artery pressure, inducing circulatory collapse and leading to right heart failure in $\mathrm{PH}$ patients. Some patients may be at risk of exercise-induced hypoxaemia, malignant arrhythmia, pulmonary artery dissection, left main coronary artery compression and even sudden death if overexertion takes place. Safety precautions were nicely illustrated in an animal model, investigating exercise training in stable versus progressive PH [74]. Exercise training may significantly decrease survival and lead to a decrease in workload in unstable and progressive compared to stable $\mathrm{PH}$. In progressive $\mathrm{PH}$, training triggered pulmonary vascular remodelling and led to an increase of right ventricular fibrosis, whereas these effects could not be observed in stable $\mathrm{PH}$ [74]. Thus, it seems essential to perform a comprehensive evaluation of $\mathrm{PH}$ patients before exercise training and safety measures should be applied during performance because serious adverse events could occur [75]. The precondition that patients be on optimised, stable, disease-targeted treatment to participate in the low-intensity, carefully monitored training programme might be the reason, why up to now, only a few adverse events $(<5 \%)$ have been reported with regards to exercise training in $\mathrm{PH}$ (table 8).

In the largest published prospective cohort study [19], in $13.6 \%$ of 183 patients adverse events occurred, and most of them were mild and not directly attributable to the exercise training itself (table 8). Mild haemoptysis was observed in a patient with acute respiratory infection, and syncope occurred hours after the training at night $(n=1)$ or when rising up from a chair $(n=1)$. These events, as well as five out of six pre-syncopal episodes did not seem to have a direct relationship to exercise training [19].

Adverse events were reported in 64 (9.5\%) out of 674 exercise-trained PH patients. Exercise-related complications seemed to be more frequent in outpatient compared to inpatient settings (5.8\% versus $4.3 \%$ ) [21, 26, 28, 34]. Interestingly, all side-effects not directly related to exercise were reported only in prospective inpatient rehabilitation cohorts from the Heidelberg (Germany) centre [16-20]. The most frequent adverse event (3.4\%) was respiratory infection [16-20], which led to antibiotic treatment and short discontinuation of the training. In only a few cases was exercise training permanently discontinued. In some studies, training protocols required minor adjustment due to dizziness $[15,20,21,28,34]$, fatigue [34] or hypotension [32]. Nonsustained supraventricular arrhythmia [19, 28], syncope [17] and pre-syncope [19] during or briefly after exercise training were reported in $<1 \%$ of all patients. Similar adverse event rates of $10 \%$ [69] and 3\% [40] were calculated in recently published meta-analyses. Clinical worsening of symptoms and heart failure was not observed in any study during exercise training.

Emergency equipment and qualified, well-trained personnel is a prerequisite during exercise training to treat potential complications. Commonly employed safety measures for rehabilitation and patient monitoring during exercise are discussed in the sections Training modalities and setting and Requirements of different healthcare systems.

Rehabilitation seems to be most effective and safe in physically deconditioned moderate-risk patients with PAH and inoperable CTEPH $[19,24]$. The lowest therapeutic range of this new PH treatment modality may be expected in patients with WHO functional class IV. While only few of them were included in the studies, they showed the largest improvement after very closely supervised, low-intensity exercise and respiratory training [19]. However, the low patient numbers do not allow valid conclusions about the safety of training in such patients. 
TABLE 8 Exercise training-associated adverse events in patients with chronic stable pulmonary hypertension

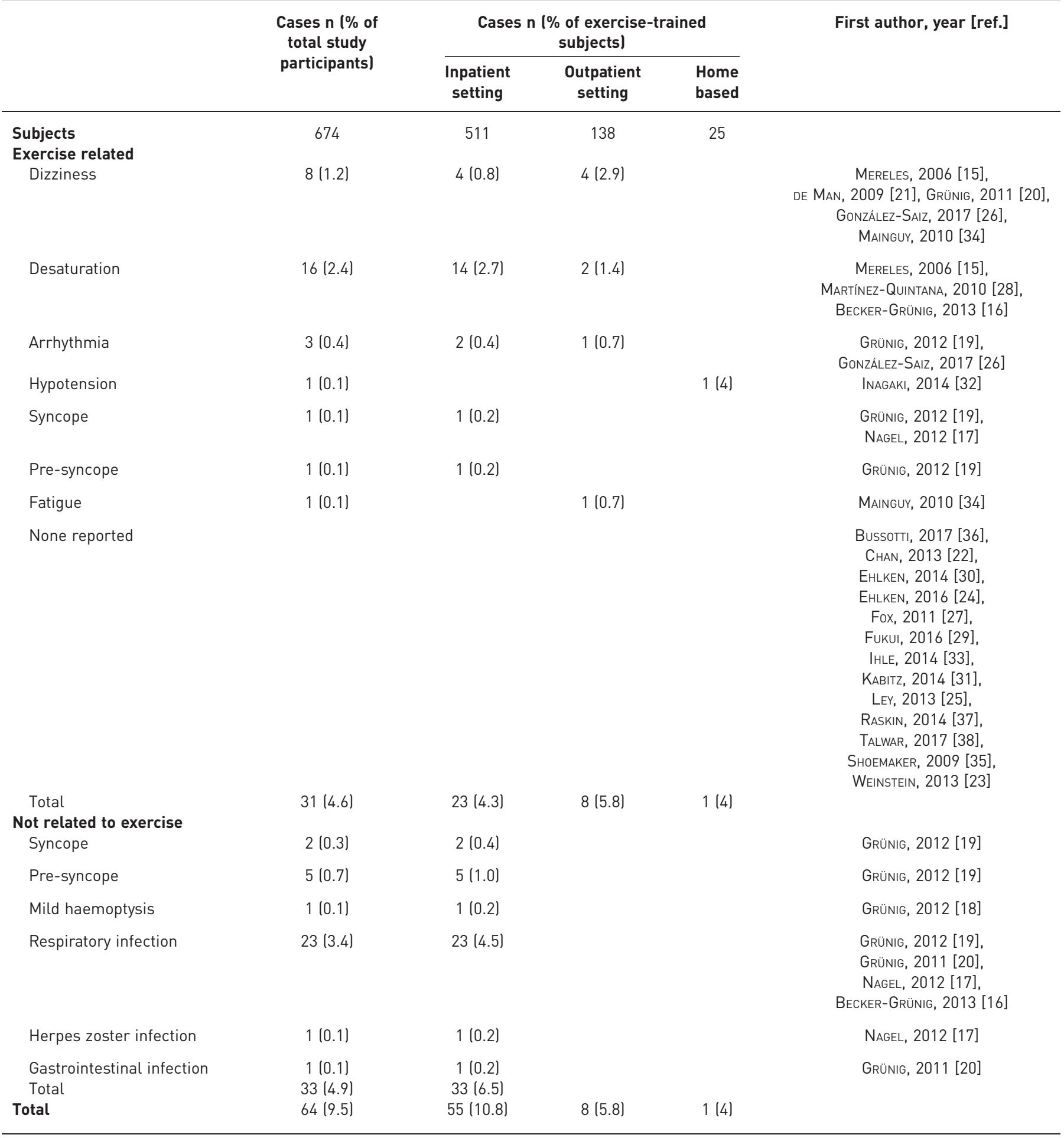

In most studies, the PAH group was mainly represented by IPAH and PAH associated with connective tissue disease (table 1). Physical training could be challenging in patients with $\mathrm{PAH}$ due to congenital heart disease and in syndromal diseases [16, 28]. Low oxygen saturation even at rest is common in patients with Eisenmenger syndrome and it may drop further during exercise despite oxygen supply. Further investigations are needed to explore the advantages and risks of training in this group. Studies should systematically compare training modalities and intensities within subgroups of PAH and CTEPH. 
In order to obtain a good safety profile, thorough patient selection and monitoring as well as highly specialised personnel are obligatory. An in-hospital beginning may further help to obtain a safe training environment and careful supervision. The cost-effectiveness of specialised training programmes still needs further investigation, as only one study with a prospective intervention and retrospective control group has demonstrated lower healthcare costs following exercise rehabilitation (with in-hospital start), compared to sole medication treatment [30].

In summary, the evidence shows that careful patient selection, appropriate setting, well-prepared multidisciplinary teams from $\mathrm{PH}$ and rehabilitation specialists, individualised and flexible exercise training protocols and close monitoring are very important in order to provide a good safety profile in patients with $\mathrm{PH}$. Using the right setting, exercise training has shown to be a safe and effective treatment, especially when applied in patients on adequate medical therapy. Therefore, participation in unspecialised training programmes or unsupervised settings, e.g. home training is dissuaded. Strenuous exercise should still remain contraindicated in patients with $\mathrm{PH}[1]$.

\section{Part III: implementation of exercise training \\ Participant selection, compliance and motivation}

The process of successful patient participation in a $\mathrm{PH}$-specific exercise therapy programme involves four key steps (figure 1).

\section{Patient selection}

Patients must have confirmed $\mathrm{PH}$ in a clinically stable condition, with no $\mathrm{PH}$-specific treatment changes for 2 months [19].

Additional considerations should be made on an individual patient basis, as follows.

- Age: $18-80$ years is the range in which the therapy has been most widely studied.

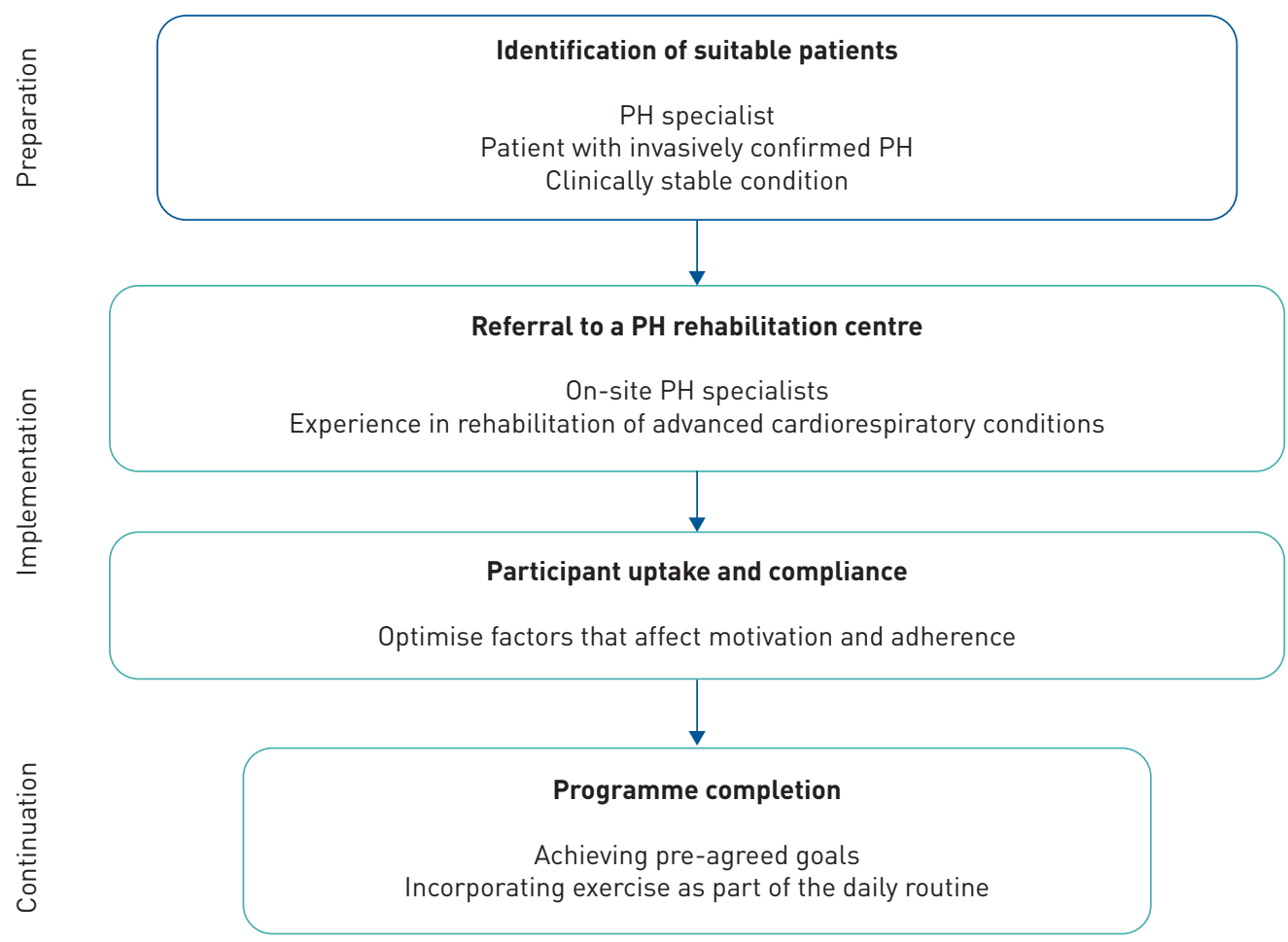

FIGURE 1 Four key steps for successful patient participation in an exercise training programme. These steps describe the way the participation of patients with pulmonary hypertension $(\mathrm{PH})$ is enhanced in specialised programmes. It is not intended as a recommendation. As preparation for the programme, suitable patients must be identified. The programme is implemented together with a rehabilitation centre enhancing patients' motivation. After completion of the programme, a continuation of exercises in the daily routine helps to maintain the training effect. 
- Medical therapy: exercise therapy improves exercise capacity and QoL in patients on mono-, dual and triple therapy. The optimal timing of exercise therapy in relation to treatment changes is unclear and requires further research.

- Determining the likelihood of improvement: this is an under-studied area in all forms of cardiorespiratory rehabilitation. In cardiac rehabilitation, patients with impaired chronotropic response have poorer outcomes following cardiac rehabilitation [76]. In chronic obstructive pulmonary disease, those who responded favourably to rehabilitation had a higher symptom burden, lower frequency of hospital admissions and poorer baseline exercise performance [77]. GRÜNIG et al. [19] found that PAH patients with $<15 \%$ improvement in $6 \mathrm{MWD}$ following rehabilitation were more likely to have associated $\mathrm{PAH}$; recurrent respiratory tract infection; orthopaedic problems; significant/untreated depression and anxiety; baseline $6 \mathrm{MWD}>550 \mathrm{~m}$; recently completed a training programme

As $\mathrm{PH}$ is a rare disease and patients have to be in stable condition to participate in an exercise training programme, a strong involvement of the $\mathrm{PH}$ expert centre in patient selection, supervision and conductance of exercise training seems desirable. Increasing awareness in $\mathrm{PH}$ expert centres may therefore enhance referral and patient access to this treatment.

\section{Compliance}

In $\mathrm{PH}$-specific rehabilitation, compliance ranges from $58 \%$ to $100 \%$ and benefits are dose-dependent [26]. Dedicated studies have not assessed factors that influence or improve compliance in PAH. These areas have been more closely studied in cardiac and pulmonary rehabilitation [78, 79]. Common factors associated with reduced compliance are environmental (work commitments, travel, disruption to the patients' usual routine, cost burden); medical (current smokers, lower baseline functional status, higher body mass index); and patient and physician beliefs (too ill or not ill enough, beliefs around the role or safety of exercise, cultural reasons).

Developing an individualised therapy programme, psychological support, regular telephone or email support and involving a family or friend in the exercise routine have all been shown to enhance compliance. Furthermore, education on the disease, exercise pathophysiology and the influence of activity on the body may help to increase patient motivation and good conduct of the programme.

\section{Motivation}

Patient motivation and education directly influence compliance. Validated strategies exist to enhance motivation [19]. According to the American Thoracic Society (ATS)/ERS statement on pulmonary rehabilitation, patient self-management may be enhanced by thorough education and support of self-efficacy by goal-setting and motivation [80]. Long-term, realistic goal setting usually takes place at the beginning of a programme; goals are contextualised and adjusted as needed; in addition, specific psychological techniques such as mental imagery can be employed with specialist training of staff [15].

In conclusion, a thorough patient selection process seems to be crucial for the outcome of exercise rehabilitation. While general recommendations to enhance compliance may be implemented, studies are needed to find the optimal strategy for long-term continuation of exercise training in patients with $\mathrm{PH}$.

\section{Requirements of different healthcare systems}

While the 2015 ESC/ERS guidelines recommend supervised exercise training for stable $\mathrm{PH}$ patients in a supervised and monitored setting [1], in many European countries specialised $\mathrm{PH}$-training programmes are not yet available. The ATS/ERS policy statement recommends that patient access to rehabilitation programmes be enhanced by the introduction of rehabilitation facilities offering these specialised training programmes, the performance of quality control assessment, e.g. by assessing outcomes and conducting scientific trials. Furthermore, cost-effectiveness analyses in future trials may help to convince healthcare providers and payers of the beneficial effects of exercise training in this patient cohort [81].

Official information on the requirement of healthcare systems for the implementation of such programmes for $\mathrm{PH}$ in different countries is scarce, therefore this issue has been discussed within this task force involving 18 centres in 11 European countries to get a better understanding of local conditions. Furthermore, it was the aim of this task force to summarise crucial aspects, such as training modalities and settings, physical conditions of the facilities, safety measures and which professionals should be involved. Implementation of these programmes is greatly dependent on the organisation of healthcare systems and financing models in each country. Most of the countries have a national healthcare system exclusively public $(n=4)$ or complemented by private insurance $(n=7)$. In $10(91 \%)$ out of the 11 countries, costs of exercise and rehabilitation programmes for chronic diseases are fully covered by the public or mixed healthcare system. As exercise training and rehabilitation in $\mathrm{PH}$ requires increased attention and 
organisational effort, reimbursement often does not cover the full costs of such an intervention. Many European countries such as the United Kingdom, Ireland and Spain do not have rehabilitation clinics/ facilities which could be used for an in-hospital start of the exercise training programme. Nevertheless, specialised $\mathrm{PAH} / \mathrm{PH}$-referral centres of 10 European countries started in cooperation with rehabilitation facilities with exercise and rehabilitation programmes for chronic $\mathrm{PH}$ within this task force project. Most of the involved rehabilitation units have facilities and equipment that allows common training modalities for chronic PH (aerobic, muscle, mental gait and respiratory) and multidisciplinary (physiatrist and/or cardiologist and/or pulmonologist) and multiprofessional (exercise physiologist and/or physical therapist and/or nurse) teams. All units are equipped with emergency equipment in the gym or nearby, and have emergency trained personnel on-site.

Most of the participating centres include aerobic, muscle and respiratory training in an exercise and rehabilitation programme for chronic $\mathrm{PH}$ as well as mental gait training. Physical therapists and nurses were considered essential for the programme (100\% and $90 \%$, respectively), as well as a cardiologist (90\%) and/or pulmonologist (90\%) and/or a physiatrist (50\%). Emergency equipment and trained personnel were available in all participating centres.

Most respondents considered exercise and rehabilitation programmes for chronic $\mathrm{PH}$ to be validated (92\%), essential (75\%) and useful (100\%). Such programmes are available in a case-by-case analysis in the majority of participating centres.

In summary, the establishment of specialised rehabilitation programmes for $\mathrm{PH}$ patients would further patient access to this treatment intervention. A multiprofessional and multidisciplinary setting, as well as quality control measures seem desirable for this patient cohort. As exercise training appears to be effective, cost-efficient and safe, but is scarcely sufficiently and sustainably reimbursed and supported by healthcare systems, an increased awareness among and support by healthcare institutions, commissioners of healthcare and research funding institutions are of high need. Supported by the PAH self-help group, members of this task force started an initiative to provide a standardised $\mathrm{PH}$ rehabilitation programme in their $\mathrm{PH}$ centres to make this therapy available for the patients within each of their countries.

\section{Part IV: mechanisms of action of exercise training in $\mathrm{PH}$}

The exercise limitation in $\mathrm{PAH}$ is multifactorial. It is caused by right ventricular dysfunction, chronotropic incompetence, ventilatory abnormalities and skeletal muscle dysfunction. Mechanisms of exercise intolerance are more complex than initially expected, probably including respiratory muscle weakness, dynamic hyperinflation and mechanical constraints [82], poor skeletal muscle and cerebral oxygenation [83-85], hyperventilation and enhanced sympathetic drive. Likewise, exercise training improves the function of different body organs such as heart, lung and skeletal muscle (figure 2). Exercise can modulate several mechanisms acknowledged in PAH pathophysiology such as oxidative stress, inflammation, vasoconstriction, vascular remodelling and thrombosis.

Compared to controls, PAH patients randomised to exercise training showed an increased 6MWD, peak $V^{\prime} \mathrm{O}_{2}$ and maximal workload. These can be partially attributed to improved haemodynamics at rest and during exercise with lower mean pulmonary arterial pressure and pulmonary vascular resistance, and increased stroke volume, cardiac index and cardiac output [24, 40, 41].

The mechanisms of improved haemodynamics and exercise capacity by exercise training in $\mathrm{PAH}$ and CTEPH remain incompletely understood. Decreased pulmonary artery pressure in the presence of an increased cardiac output strongly suggests a decrease in pulmonary vascular tone, but whether there might also be structural changes ("reverse remodelling") in the pulmonary vessels is not known. Increased cardiac output at rest and at maximum exercise may be explained either by a decreased afterload of the right ventricle, or a direct myocardial training effect. Finally, improved exercise capacity is at least in part to be explained by improved skeletal muscle function, but there are no reported direct measurements of an improved diffusional muscle oxygen uptake by exercise training. To clarify these issues, further research on the effects of exercise training in severe $\mathrm{PH}$ should consider the following end-points of dedicated studies: pulmonary vascular function defined by multipoint pulmonary vascular pressure/flow plots [86]; right ventriculo-arterial coupling defined by pressure-volume relationships [87]; and the coupling of convectional and diffusional mechanisms of oxygen delivery [88].

Besides the effects on the muscular system (see section on Muscle function), there is some evidence, that exercise training may also affect the pulmonary vasculature. In animal $\mathrm{PH}$ models, inconsistent results on the impact of exercise training on pulmonary vascular remodelling had been reported with unchanged, increased and reduced pulmonary arterial hypertrophy across different studies [89]. However, several animal models detected a beneficial effect of training on the right ventricle as an increase of right ventricular capillary density $(+86 \%, \mathrm{p}<0.05)$ up to near-normal values, a reduction of right ventricular 


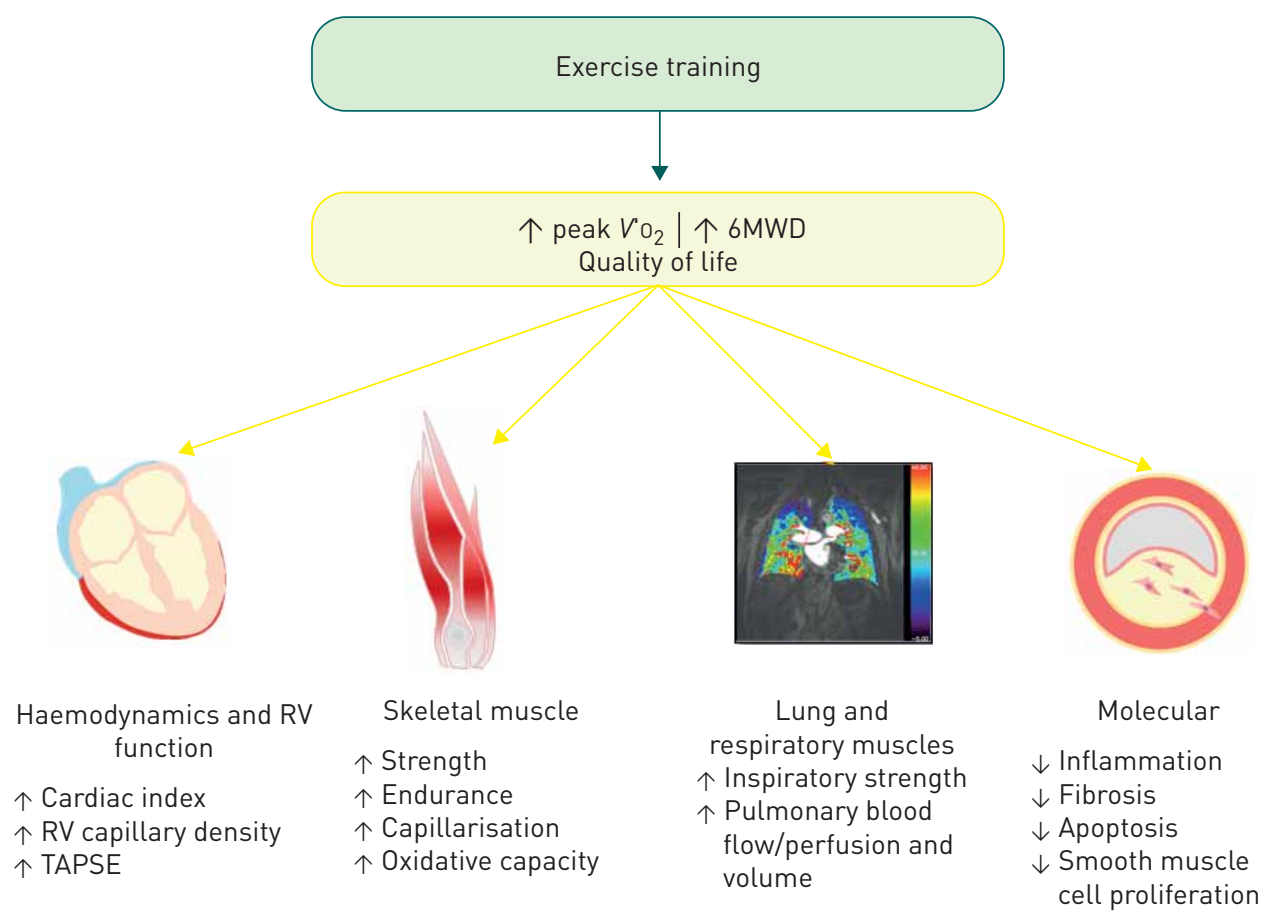

FIGURE 2 Main physiological effects of exercise training. Exercise training in pulmonary hypertension acts upon heart function and skeletal and respiratory muscles, on a macroscopic as well as molecular level. Inflammation and cell proliferation are reduced. 6MWD: 6-min walk distance; peak $\mathrm{V}^{\prime} \mathrm{O}_{2}$ : peak oxygen uptake; RV: right ventricular; TAPSE: tricuspid annular plane systolic excursion.

end-diastolic pressure $[74,90]$ and reduction of interstitial volume $(-60 \%, p<0.05)$ [74]. There are no histological data available on human PAH vessels. The precise molecular impact of exercise training on right ventricular function remains unclear. In $\mathrm{PH}$ rats, exercise training improved right ventricular function assessed by echocardiography (tricuspid annular plane maximal systolic velocity, tricuspid annular plane systolic excursion) and invasive haemodynamics (end-diastolic and end-systolic pressurevolume relationship) [91]. These functional changes were associated with an anti-inflammatory, antifibrotic and antiapoptotic effect [91]. In addition, a reduced oxidative stress and improved neurohumoral markers (lower N-terminal pro-brain natriuretic peptide (NT-proBNP) and endothelin-1 myocardial expression) were described in the right ventricle of trained $\mathrm{PH}$ animals. In contrast, in only one out of six studies a significant improvement of plasma NT-proBNP levels [17] was described in patients undergoing exercise training (table 7). One study in patients with congenital heart disease-associated pulmonary arterial hypertension even showed a significant increase of NT-proBNP after the training intervention [16].

In a contrast-enhanced magnetic resonance imaging based study, a significant increase of lung perfusion in 20 patients with PAH and CTEPH could be detected after exercise training [25]. Although the training was only short ( 3 weeks duration), patients showed a significant improvement of mean flow velocity and perfusion (mean pulmonary blood volume) of the lung (figure 2). This result might be evoked by a modulating effect on pulmonary vascular remodelling. Consistently, exercise training prevented skeletal muscle wasting and modulated muscle proteolysis pathways (Akt, mammalian target of rapamycin) in $\mathrm{PH}$ animal models.

Exercise training was able to improve hypoxia-induced pulmonary vascular remodelling in mice to the same extent as sildenafil treatment [92]. However, the underlying pathobiological mechanisms are indistinct, as exercise training did not change the targeted pathways for medication treatment including nitric oxide/phosphodiesterase-5/soluble guanylate cyclase pathways.

Despite the remarkable advances recently made in understanding the pathobiology of $\mathrm{PAH}$, the mechanistic understanding of the functional improvement of PAH patients undergoing exercise training is still limited. A combined effect on different molecular pathways and organs is likely to be the pathophysiological underpinning of the improvement associated with exercise training in PH. Further 
research is needed to elucidate the relevance of each of these mechanisms, in particular the direct influence on right ventricular function and pulmonary vascular disease progression. It is also of great interest, if exercise training leads to epigenetic changes which may modulate several $\mathrm{PH}$ pathways.

\section{Summary}

The evidence summarised in this statement suggests that individually adjusted exercise training rehabilitation programmes supervised by $\mathrm{PH}$ expert centres and rehabilitation professionals are likely to be safe for patients with $\mathrm{PH}$ who are stable on medical therapy. Exercise training can lead to meaningful improvements in exercise capacity, muscular function, QoL and possibly right ventricular function and pulmonary haemodynamics [3]. Beneficial effects of exercise training have been shown in six randomised controlled trials [15, 22-26], three controlled trials [27-29], 10 prospective cohort studies [16-21, 30-35], three case series [34-36], two retrospective cohort studies [37, 38] and four meta-analyses [39-41] including one Cochrane review [42]. Beside the clinical effects, it has also been shown that exercise training may reduce inflammation and cell proliferation on a molecular level and may have a beneficial effect on the pulmonary vessels.

Further randomised controlled trials are needed to confirm the data on the effect of exercise training on clinical parameters as right ventricular function and haemodynamics. Although there is no direct evidence for an impact of exercise training on survival in $\mathrm{PH}$, several studies suggest a beneficial effect on prognostically important parameters. Studies with survival and time to clinical worsening as primary outcome are hindered by ethical and methodological aspects. Therefore, a future approach to this question could be to investigate the impact of exercise training on risk profiles in PH. Furthermore, the most advantageous training methodology including setting, monitoring, modality, frequency, intensity and length of the training programme still needs to be determined. Further pathophysiological research is needed for a better understanding of the mechanisms by which exercise training is beneficial to patients with severe $\mathrm{PH}$.

In summary, the establishment of specialised rehabilitation programmes for $\mathrm{PH}$ patients would further patient access to this treatment intervention. As exercise training appears to be effective, cost-efficient and safe, but is scarcely reimbursed and supported by healthcare systems, an increased awareness among and support from healthcare institutions, commissioners of healthcare and research funding institutions are of high need. Supported by the PAH self-help group, the members of this ERS task force including 10 European countries started the initiative to provide a standardised $\mathrm{PH}$ rehabilitation programme in their centres to make this therapy available for the patients within their country and to implement this nonpharmacological intervention into standard care.

Acknowledgements: We would like to thank the Pulmonary Hypertension Association (PHA) and the pulmonary hypertension self-help group ph e.v.

Conflict of interest: E. Grünig reports grants and personal fees from Actelion and Bayer/MSD, grants from GSK, United Therapeutics and Novartis, and personal fees from SCOPE, OrPha Swiss GmbH and Zurich Heart House, outside the submitted work. C. Eichstaedt has nothing to disclose. J-A. Barberà has nothing to disclose. N. Benjamin reports personal fees for speaking from Bayer and Actelion, outside the submitted work. I. Blanco has nothing to disclose. E. Bossone has nothing to disclose. A. Cittadini has nothing to disclose. G. Coghlan has nothing to disclose. P. Corris reports grants and personal fees from Actelion and Bayer, and personal fees from MSD, outside the submitted work. M. D'Alto has nothing to disclose. A. D'Andrea has nothing to disclose. M. Delcroix has nothing to disclose. F. de Man has nothing to disclose. S. Gaine reports personal fees from Actelion, United Therapeutics, MSD and GSK, outside the submitted work. S. Ghio has nothing to disclose. S. Gibbs reports grants and personal fees from Actelion, Bayer and MSD, personal fees from Arena, Bellopheron, Acceleron, Complexa and Pfizer, and grants from GSK, Amco and United Therapeutics, during the conduct of the study. L. Gumbiene has nothing to disclose. L.S. Howard has nothing to disclose. M. Johnson reports research grants and personal fees for attendance at meeting and speaking from Actelion, Bayer, GSK and MSD, outside the submitted work. E. Jurevičiene has nothing to disclose. D.G. Kiely reports grants, personal fees and non-financial support from Actelion, Bayer and GSK, and personal fees and non-financial support from MSD, outside the submitted work. G. Kovacs reports personal fees for lecturing, travel support and advisory board work from Actelion and MSD, personal fees for lecturing and advisory board work from GSK, personal fees for lecturing, consultancy and advisory board work from Boehringer Ingelheim and Chiesi, personal fees for lecturing and travel support from Bayer, and personal fees for lecturing from Pfizer and Novartis, outside the submitted work. A. MacKenzie has nothing to disclose. A.M. Marra reports a grant for Young Researcher (Principal Investigator "Ricerca Finalizzata under 40" n. GR-2016-02364727) from the Italian Healthcare Ministry, and personal fees for lecturing from Bayer Healthcare, during the conduct of the study. N. McCaffrey has nothing to disclose. P. McCaughey has nothing to disclose. R. Naeije has nothing to disclose. H. Olschewski reports personal fees and non-financial support from Bayer, MSD, Pfizer and Novartis, grants, personal fees and non-financial support from Actelion, grants from Inventiva, and personal fees from Bellerophon, outside the submitted work; and is a part time employee of Ludwig Boltzmann Insitute for Lung Vascular Research. J. Pepke-Zaba or her institution have received educational/research grants and J. Pepke-Zaba serves on advisory boards for Actelion, Merck, Bayer and GSK. A. Reis has nothing to disclose. M. Santos has nothing to disclose. S. Saxer has nothing to disclose. R.M. Tulloh has received honoraria and speaker fees from Actelion, Pfizer, Bayer and GSK. S. Ulrich reports grants from Swiss National Science Foundation and Zurich Lung, 
grants and personal fees from Actelion SA and Orpha Swiss, and personal fees from MSD SA, outside the submitted work. A. Vonk Noordegraaf reports speaker fees from Actelion, and grants from MSD, Actelion and GSK, outside the submitted work. A.J. Peacock reports grants from Actelion, Bayer and GSK, and personal fees from MSD and Arena, outside the submitted work.

Support statement: This work was funded by the European Respiratory Society (TF-2015-17). Funding information for this article has been deposited with the Crossref Funder Registry.

\section{References}

1 Galiè N, Humbert M, Vachiery JL, et al. 2015 ESC/ERS Guidelines for the diagnosis and treatment of pulmonary hypertension: The Joint Task Force for the Diagnosis and Treatment of Pulmonary Hypertension of the European Society of Cardiology (ESC) and the European Respiratory Society (ERS). Eur Respir J 2015; 46: 903-975.

2 Hoeper MM, Huscher D, Ghofrani HA, et al. Elderly patients diagnosed with idiopathic pulmonary arterial hypertension: results from the COMPERA registry. Int J Cardiol 2013; 168: 871-880.

3 Garber CE, Blissmer B, Deschenes MR, et al. American College of Sports Medicine position stand. Quantity and quality of exercise for developing and maintaining cardiorespiratory, musculoskeletal, and neuromotor fitness in apparently healthy adults: guidance for prescribing exercise. Med Sci Sports Exerc 2011; 43: 1334-1359.

4 D'Andrea A, Riegler L, Golia E, et al. Range of right heart measurements in top-level athletes: the training impact. Int J Cardiol 2013; 164: 48-57.

5 D'Andrea A, Riegler L, Morra S, et al. Right ventricular morphology and function in top-level athletes: a three-dimensional echocardiographic study. J Am Soc Echocardiogr 2012; 25: 1268-1276.

6 Bhella PS, Hastings JL, Fujimoto N, et al. Impact of lifelong exercise "dose" on left ventricular compliance and distensibility. J Am Coll Cardiol 2014; 64: 1257-1266.

7 Diaz KM, Goldsmith J, Greenlee H, et al. Prolonged, uninterrupted sedentary behavior and glycemic biomarkers among US Hispanic/Latino adults: the Hispanic Community Health Study/Study of Latinos (HCHS/SOL). Circulation 2017; 136: 1362-1373.

8 Piepoli MF, Hoes AW, Agewall S, et al. 2016 European Guidelines on cardiovascular disease prevention in clinica practice: The Sixth Joint Task Force of the European Society of Cardiology and Other Societies on Cardiovascular Disease Prevention in Clinical Practice (constituted by representatives of 10 societies and by invited experts). Developed with the special contribution of the European Association for Cardiovascular Prevention \& Rehabilitation (EACPR). Eur Heart J 2016; 37: 2315-2381.

9 Ponikowski P, Voors AA, Anker SD, et al. 2016 ESC Guidelines for the diagnosis and treatment of acute and chronic heart failure: The Task Force for the diagnosis and treatment of acute and chronic heart failure of the European Society of Cardiology (ESC). Developed with the special contribution of the Heart Failure Association (HFA) of the ESC. Eur Heart J 2016; 37: 2129-2200.

10 Taylor RS, Sagar VA, Davies EJ, et al. Exercise-based rehabilitation for heart failure. Cochrane Database Syst Rev 2014: CD003331.

11 Hegde SM, Claggett B, Shah AM, et al. Physical Activity and Prognosis in the TOPCAT Trial (Treatment of Preserved Cardiac Function Heart Failure With an Aldosterone Antagonist). Circulation 2017; 136: 982-992.

12 Edelmann F, Gelbrich G, Düngen HD, et al. Exercise training improves exercise capacity and diastolic function in patients with heart failure with preserved ejection fraction: results of the Ex-DHF (Exercise training in Diastolic Heart Failure) pilot study. J Am Coll Cardiol 2011; 58: 1780-1791.

13 Mittelman MA, Maclure M, Tofler GH, et al. Triggering of acute myocardial infarction by heavy physical exertion. N Engl J Med 1993; 329: 1677-1683.

14 Montalescot G, Sechtem U, Achenbach S, et al. 2013 ESC guidelines on the management of stable coronary artery disease: the Task Force on the management of stable coronary artery disease of the European Society of Cardiology. Eur Heart J 2013; 34: 2949-3003.

15 Mereles D, Ehlken N, Kreuscher S, et al. Exercise and respiratory training improve exercise capacity and quality of life in patients with severe chronic pulmonary hypertension. Circulation 2006; 114: 1482-1489.

16 Becker-Grünig $\mathrm{T}$, Klose $\mathrm{H}$, Ehlken $\mathrm{N}$, et al. Efficacy of exercise training in pulmonary arterial hypertension associated with congenital heart disease. Int J Cardiol 2013; 168: 375-381.

17 Nagel C, Prange F, Guth S, et al. Exercise training improves exercise capacity and quality of life in patients with inoperable or residual chronic thromboembolic pulmonary hypertension. PLoS One 2012; 7: e41603.

18 Grünig E, Maier F, Ehlken N, et al. Exercise training in pulmonary arterial hypertension associated with connective tissue diseases. Arthritis Res Ther 2012; 14: R148.

19 Grünig E, Lichtblau M, Ehlken N, et al. Safety and efficacy of exercise training in various forms of pulmonary hypertension. Eur Respir J 2012; 40: 84-92.

20 Grünig E, Ehlken N, Ghofrani A, et al. Effect of exercise and respiratory training on clinical progression and survival in patients with severe chronic pulmonary hypertension. Respiration 2011; 81: 394-401.

21 de Man FS, Handoko ML, Groepenhoff $\mathrm{H}$, et al. Effects of exercise training in patients with idiopathic pulmonary arterial hypertension. Eur Respir J 2009; 34: 669-675.

22 Chan L, Chin LM, Kennedy M, et al. Benefits of intensive treadmill exercise training on cardiorespiratory function and quality of life in patients with pulmonary hypertension. Chest 2013; 143: 333-343.

23 Weinstein AA, Chin LM, Keyser RE, et al. Effect of aerobic exercise training on fatigue and physical activity in patients with pulmonary arterial hypertension. Respir Med 2013; 107: 778-784.

24 Ehlken N, Lichtblau M, Klose $\mathrm{H}$, et al. Exercise training improves peak oxygen consumption and haemodynamics in patients with severe pulmonary arterial hypertension and inoperable chronic thrombo-embolic pulmonary hypertension: a prospective, randomized, controlled trial. Eur Heart J 2016; 37: 35-44.

25 Ley S, Fink C, Risse F, et al. Magnetic resonance imaging to assess the effect of exercise training on pulmonary perfusion and blood flow in patients with pulmonary hypertension. Eur Radiol 2013; 23: 324-331.

26 González-Saiz L, Fiuza-Luces C, Sanchis-Gomar F, et al. Benefits of skeletal-muscle exercise training in pulmonary arterial hypertension: The WHOLEi+12 trial. Int J Cardiol 2017; 231: 277-283. 
27 Fox BD, Kassirer M, Weiss I, et al. Ambulatory rehabilitation improves exercise capacity in patients with pulmonary hypertension. J Card Fail 2011; 17: 196-200.

28 Martínez-Quintana E, Miranda-Calderín G, Ugarte-Lopetegui A, et al. Rehabilitation program in adult congenital heart disease patients with pulmonary hypertension. Congenit Heart Dis 2010; 5: 44-50.

29 Fukui S, Ogo T, Takaki H, et al. Efficacy of cardiac rehabilitation after balloon pulmonary angioplasty for chronic thromboembolic pulmonary hypertension. Heart 2016; 102: 1403-1409.

30 Ehlken N, Verduyn C, Tiede H, et al. Economic evaluation of exercise training in patients with pulmonary hypertension. Lung 2014; 192: 359-366.

31 Kabitz HJ, Bremer HC, Schwoerer A, et al. The combination of exercise and respiratory training improves respiratory muscle function in pulmonary hypertension. Lung 2014; 192: 321-328.

32 Inagaki T, Terada J, Tanabe N, et al. Home-based pulmonary rehabilitation in patients with inoperable or residual chronic thromboembolic pulmonary hypertension: a preliminary study. Respir Investig 2014; 52: 357-364.

33 Ihle $\mathrm{F}$, Weise S, Waelde A, et al. An integrated outpatient training program for patients with pulmonary hypertension - the Munich Pilot Project. Int J Phys Med Rehab 2014; 2: 204.

34 Mainguy V, Maltais F, Saey D, et al. Effects of a rehabilitation program on skeletal muscle function in idiopathic pulmonary arterial hypertension. J Cardiopulm Rehabil Prev 2010; 30: 319-323.

35 Shoemaker MJ, Wilt JL, Dasgupta R, et al. Exercise training in patients with pulmonary arterial hypertension: a case report. Cardiopulm Phys Ther J 2009; 20: 12-18.

36 Bussotti M, Gremigni P, Pedretti RFE, et al. Effects of an outpatient service rehabilitation programme in patients affected by pulmonary arterial hypertension: an observational study. Cardiovasc Hematol Disord Drug Targets 2017; 17: 3-10.

37 Raskin J, Qua D, Marks T, et al. A retrospective study on the effects of pulmonary rehabilitation in patients with pulmonary hypertension. Chron Respir Dis 2014; 11: 153-162.

38 Talwar A, Sahni S, Verma S, et al. Exercise tolerance improves after pulmonary rehabilitation in pulmonary hypertension patients. J Exerc Rehabil 2017; 13: 214-217.

39 Buys R, Avila A, Cornelissen VA. Exercise training improves physical fitness in patients with pulmonary arterial hypertension: a systematic review and meta-analysis of controlled trials. BMC Pulm Med 2015; 15: 40.

40 Pandey A, Garg S, Khunger M, et al. Efficacy and safety of exercise training in chronic pulmonary hypertension: systematic review and meta-analysis. Circ Heart Fail 2015; 8: 1032-1043.

41 Yuan P, Yuan XT, Sun XY, et al. Exercise training for pulmonary hypertension: a systematic review and meta-analysis. Int J Cardiol 2015; 178: 142-146.

42 Morris NR, Kermeen FD, Holland AE. Exercise-based rehabilitation programmes for pulmonary hypertension Cochrane Database Syst Rev 2017; 1: CD011285.

43 Zöller D, Siaplaouras J, Apitz A, et al. Home exercise training in children and adolescents with pulmonary arterial hypertension: a pilot study. Pediatr Cardiol 2017; 38: 191-198.

44 Gerhardt F, Dumitrescu D, Gärtner C, et al. Oscillatory whole-body vibration improves exercise capacity and physical performance in pulmonary arterial hypertension: a randomised clinical study. Heart 2017; 103: 592-598.

45 Chaouat A, Sitbon O, Mercy M, et al. Prognostic value of exercise pulmonary haemodynamics in pulmonary arterial hypertension. Eur Respir J 2014; 44: 704-713.

46 Sun XG, Hansen JE, Oudiz RJ, et al. Exercise pathophysiology in patients with primary pulmonary hypertension. Circulation 2001; 104: 429-435.

47 Kabitz HJ, Schwoerer A, Bremer HC, et al. Impairment of respiratory muscle function in pulmonary hypertension. Clin Sci 2008; 114: 165-171.

48 Mainguy V, Maltais F, Saey D, et al. Peripheral muscle dysfunction in idiopathic pulmonary arterial hypertension. Thorax 2010; 65: 113-117.

49 Meyer FJ, Lossnitzer D, Kristen AV, et al. Respiratory muscle dysfunction in idiopathic pulmonary arterial hypertension. Eur Respir J 2005; 25: 125-130.

50 de Man FS, van Hees HW, Handoko ML, et al. Diaphragm muscle fiber weakness in pulmonary hypertension. Am J Respir Crit Care Med 2011; 183: 1411-1418.

51 Manders E, Bonta PI, Kloek JJ, et al. Reduced force of diaphragm muscle fibers in patients with chronic thromboembolic pulmonary hypertension. Am J Physiol Lung Cell Mol Physiol 2016; 311: L20-L28.

52 Manders E, de Man FS, Handoko ML, et al. Diaphragm weakness in pulmonary arterial hypertension: role of sarcomeric dysfunction. Am J Physiol Lung Cell Mol Physiol 2012; 303: L1070-L1078.

53 Batt J, Ahmed SS, Correa J, et al. Skeletal muscle dysfunction in idiopathic pulmonary arterial hypertension. Am J Respir Cell Mol Biol 2014; 50: 74-86.

54 Wüst RC, Myers DS, Stones R, et al. Regional skeletal muscle remodeling and mitochondrial dysfunction in right ventricular heart failure. Am J Physiol Heart Circ Physiol 2012; 302: H402-H411.

55 Potus F, Malenfant S, Graydon C, et al. Impaired angiogenesis and peripheral muscle microcirculation loss contribute to exercise intolerance in pulmonary arterial hypertension. Am J Respir Crit Care Med 2014; 190: 318-328.

56 Vescovo G, Ceconi C, Bernocchi P, et al. Skeletal muscle myosin heavy chain expression in rats with monocrotaline-induced cardiac hypertrophy and failure. Relation to blood flow and degree of muscle atrophy. Cardiovasc Res 1998; 39: 233-241.

57 Manders E, Ruiter G, Bogaard HJ, et al. Quadriceps muscle fibre dysfunction in patients with pulmonary arterial hypertension. Eur Respir J 2015; 45: 1737-1740.

58 Manders E, Rain S, Bogaard HJ, et al. The striated muscles in pulmonary arterial hypertension: adaptations beyond the right ventricle. Eur Respir J 2015; 46: 832-842.

59 Panagiotou M, Peacock AJ, Johnson MK. Respiratory and limb muscle dysfunction in pulmonary arterial hypertension: a role for exercise training? Pulm Circ 2015; 5: 424-434.

60 Mello PR, Guerra GM, Borile S, et al. Inspiratory muscle training reduces sympathetic nervous activity and improves inspiratory muscle weakness and quality of life in patients with chronic heart failure: a clinical trial. J Cardiopulm Rehabil Prev 2012; 32: 255-261.

61 Gaine S, Simonneau G. The need to move from 6-minute walk distance to outcome trials in pulmonary arterial hypertension. Eur Respir Rev 2013; 22: 487-494. 
62 Galiè N, Manes A, Palazzini M. Exercise training in pulmonary hypertension: improving performance but waiting for outcome. Eur Heart J 2016; 37: 45-48.

63 Holmes MD, Chen WY, Feskanich D, et al. Physical activity and survival after breast cancer diagnosis. JAMA 2005; 293: 2479-2486.

64 Kenfield SA, Stampfer MJ, Giovannucci E, et al. Physical activity and survival after prostate cancer diagnosis in the health professionals follow-up study. J Clin Oncol 2011; 29: 726-732.

65 Groepenhoff $\mathrm{H}$, Vonk-Noordegraaf A, Boonstra A, et al. Exercise testing to estimate survival in pulmonary hypertension. Med Sci Sports Exerc 2008; 40: 1725-1732.

66 Ulrich S, Fischler M, Speich R, et al. Wrist actigraphy predicts outcome in patients with pulmonary hypertension. Respiration 2013; 86: 45-51.

67 Grünig E, Benjamin N. Rehabilitation. In: Peacock AJ, Naeije R, Rubin LJ, eds. Pulmonary Circulation: Diseases and Their Treatment. 4th Edn. Boca Raton, Taylor \& Francis, 2016; pp. 361-370.

68 Marra AM, Egenlauf B, Bossone E, et al. Principles of rehabilitation and reactivation: pulmonary hypertension. Respiration 2015; 89: 265-273.

69 Babu AS, Padmakumar R, Maiya AG, et al. Effects of exercise training on exercise capacity in pulmonary arterial hypertension: a systematic review of clinical trials. Heart Lung Circ 2016; 25: 333-341.

70 Wensel R, Opitz CF, Anker SD, et al. Assessment of survival in patients with primary pulmonary hypertension: importance of cardiopulmonary exercise testing. Circulation 2002; 106: 319-324.

71 Wensel R, Francis DP, Meyer FJ, et al. Incremental prognostic value of cardiopulmonary exercise testing and resting haemodynamics in pulmonary arterial hypertension. Int J Cardiol 2013; 167: 1193-1198.

72 Grünig E, Tiede H, Enyimayew EO, et al. Assessment and prognostic relevance of right ventricular contractile reserve in patients with severe pulmonary hypertension. Circulation 2013; 128: 2005-2015.

73 Billings CG, Hurdman JA, Condliffe R, et al. Incremental shuttle walk test distance and autonomic dysfunction predict survival in pulmonary arterial hypertension. J Heart Lung Transplant 2017; 36: 871-879.

74 Handoko ML, de Man FS, Happé CM, et al. Opposite effects of training in rats with stable and progressive pulmonary hypertension. Circulation 2009; 120: 42-49.

75 Morris NR, Seale H, Harris J, et al. Serious adverse events during a 6-min walk test in patients with pulmonary hypertension. Eur Respir J 2015; 45: 1179-1182.

76 Schmid JP, Zurek M, Saner H. Chronotropic incompetence predicts impaired response to exercise training in heart failure patients with sinus rhythm. Eur J Prev Cardiol 2013; 20: 585-592.

77 Spruit MA, Augustin IM, Vanfleteren LE, et al. Differential response to pulmonary rehabilitation in COPD: multidimensional profiling. Eur Respir J 2015; 46: 1625-1635.

78 Ades PA, Keteyian SJ, Wright JS, et al. Increasing cardiac rehabilitation participation from 20\% to $70 \%$ : a road map from the Million Hearts Cardiac Rehabilitation Collaborative. Mayo Clin Proc 2017; 92: 234-242.

79 Cox NS, Oliveira CC, Lahham A, et al. Pulmonary rehabilitation referral and participation are commonly influenced by environment, knowledge, and beliefs about consequences: a systematic review using the Theoretical Domains Framework. J Physiother 2017; 63: 84-93.

80 Spruit MA, Singh SJ, Garvey C, et al. An Official American Thoracic Society/European Respiratory Society statement: key concepts and advances in pulmonary rehabilitation. Am J Respir Crit Care Med 2013; 188: e13-e64.

81 Rochester CL, Vogiatzis I, Holland AE, et al. An official American Thoracic Society/European Respiratory Society policy statement: enhancing implementation, use, and delivery of pulmonary rehabilitation. Am J Respir Crit Care Med 2015; 192: 1373-1386.

82 Laveneziana P, Garcia G, Joureau B, et al. Dynamic respiratory mechanics and exertional dyspnoea in pulmonary arterial hypertension. Eur Respir J 2013; 41: 578-587.

83 Malenfant S, Brassard P, Paquette $\mathrm{M}$, et al. Compromised cerebrovascular regulation and cerebral oxygenation in pulmonary arterial hypertension. J Am Heart Assoc 2017; 6: e006126.

84 Malenfant S, Potus F, Mainguy V, et al. Impaired skeletal muscle oxygenation and exercise tolerance in pulmonary hypertension. Med Sci Sports Exerc 2015; 47: 2273-2282.

85 Müller-Mottet S, Hildenbrand FF, Keusch S, et al. Effects of exercise and vasodilators on cerebral tissue oxygenation in pulmonary hypertension. Lung 2015; 193: 113-120.

86 Lewis GD, Bossone E, Naeije R, et al. Pulmonary vascular hemodynamic response to exercise in cardiopulmonary diseases. Circulation 2013; 128: 1470-1479.

87 Vonk Noordegraaf A, Westerhof BE, Westerhof N. The relationship between the right ventricle and its load in pulmonary hypertension. J Am Coll Cardiol 2017; 69: 236-243.

88 Esposito $\mathrm{F}$, Reese $\mathrm{V}$, Shabetai $\mathrm{R}$, et al. Isolated quadriceps training increases maximal exercise capacity in chronic heart failure: the role of skeletal muscle convective and diffusive oxygen transport. J Am Coll Cardiol 2011; 58: $1353-1362$

89 Nogueira-Ferreira R, Moreira-Gonçalves D, Santos M, et al. Mechanisms underlying the impact of exercise training in pulmonary arterial hypertension. Respir Med 2018; 134: 70-78.

90 Colombo R, Siqueira R, Becker CU, et al. Effects of exercise on monocrotaline-induced changes in right heart function and pulmonary artery remodeling in rats. Can J Physiol Pharmacol 2013; 91: 38-44.

91 Moreira-Goncalves D, Ferreira R, Fonseca H, et al. Cardioprotective effects of early and late aerobic exercise training in experimental pulmonary arterial hypertension. Basic Res Cardiol 2015; 110: 57.

92 Weissmann N, Peters DM, Klöpping C, et al. Structural and functional prevention of hypoxia-induced pulmonary hypertension by individualized exercise training in mice. Am J Physiol Lung Cell Mol Physiol 2014; 306: L986-L995. 